\title{
Households Climate Change Adaptation Strategies and Their Determinants in Drought Prone Agro-ecosystems of Northeastern Ethiopia
}

\author{
Endalew Addis ${ }^{1} \quad$ Workneh Negatu ${ }^{2} \quad$ Belay Simane ${ }^{2}$ \\ 1.Hawassa University, College of Social Sciences and Humanities, Hawassa, Ethiopia \\ 2.Addis Ababa University, College of Development Studies, Addis Ababa, Ethiopia
}

\begin{abstract}
Adaptation to climate change is mandatory to households and/or agro-ecosystems which have been affected and are also currently affected by climate variability/change to make them resilient. This will be achieved by employing appropriate adaptation strategies. This article examined the various adaptation strategies to climate change and their determinants in drought prone areas of northeastern Ethiopia focusing on Kobo and Golina districts in Amhara and Afar regions respectively. These areas depend mainly on rain-fed mixed farming agriculture and pastoral/agro-pastoral way of life. As a result, climate variability and change has created various impacts intermittently making households/agro-ecosystems vulnerable. Hence, it should be responded through appropriate adaptation strategies and practices. Accordingly, this study has tried to address these problems using mixed research approach and cross-sectional research design. Thus, data gathered from secondary sources (National Meteorological Agency), observation, key informant interviews, focus group discussions, and household survey. Consequently, quantitative data analyzed by SPSS and STATA software whereas qualitative information analyzed by content analysis. More specifically, multinomial logit model used to perform quantitative analysis. The findings have shown that there are different adaptation options determined by various determinants mainly demographic characteristics, access to or ownership of livelihood capitals, use or adoption of technologies, institutional setups and access to such institutions, and exposure of households to environmental factors. As a result, it is recommended that concerned stakeholders should work jointly to maximize the potential adaptation strategies of each household/agro-ecosystem. More specifically, mixed farming agro-ecosystems stakeholders should work jointly to tap irrigation potential and agro-pastoral and pastoral agro-ecosystems stakeholders should work to tap the potential in livestock diversification and mobility.
\end{abstract}

Keywords: climate change, vulnerability, adaptation, drought-prone, multinomial logit

DOI: $10.7176 / \mathrm{JNSR} / 13-5-01$

Publication date:March $31^{\text {st }} 2021$

\section{INTRODUCTION}

Climate change is one of the greatest challenges facing the international community in the $21^{\text {st }}$ century (Mearns and Norton, 2010). This is because, multiple independent data sources confirm beyond any reasonable doubt that the Earth's surface warmed during the $20^{\text {th }}$ century, and it is virtually certain that the Earth will continue to warm in the $21^{\text {st }}$ century (Dessler and Parson, 2006). This climate change has different impacts such as droughts, floods, and forest fires, which causes lose of homes, crop failures, reduced agricultural productivity, increased hunger, malnutrition, and disease (WDR, 2010) on different countries showing that no country is immune from various impacts of climate variability and change. Africa is highly vulnerable to climate change and climate variability as the majority of the populations depend on subsistence rain-fed agriculture (Boko et al., 2007); for instance, 85 percent of the population in Ethiopia depends on rain-fed agriculture (MOFED 2008 cited in Deressa, 2010). Furthermore, climate change impacts are more serious in drylands as they are characterized by limited water resources, and seasonal, scarce and unreliable rainfall; poorly served by infrastructures; and affected by periodic droughts (Anderson et al., 2010).

Ethiopia, listed as one of the sub-Saharan country, which is most vulnerable to climate change impacts mainly frequent droughts and floods with the least capacity to respond (Di Falco et al., 2011). Hence, climate change is one of a major development challenge to Ethiopia. For instance, since the early 1980s, Ethiopia has suffered seven major droughts of which five led to famines (World Bank, 2010). More specifically, the major droughts occurred in late 1950s in northern parts of Ethiopia, in 1972/73 northeastern part of Ethiopia in Tigray and Wollo, in 1984/85 in major parts of the country, in 1994 in lowland pastoral areas of Ethiopia, in 2000 in southern lowland pastoral areas of Ethiopia, in 2002/3 in major parts of the country, and in 2007/8 in many highland and lowlands areas of Ethiopia (World Bank, 2010). Of these, the 1984/85 drought reduced Ethiopia's agricultural production by 21 percent, which led to a 9.7 percent fall in the GDP (World Bank, 2006). Crop and livestock losses over northeastern Ethiopia, associated with droughts during 1998-2000, estimated at US\$266 per household, which is greater than the average annual income for 75 percent of households in this region (Stern, 2007). Thus, given the nature of Ethiopia's economy, which largely depends on weather-sensitive and small-scale agricultural practices and the 
low adaptive capacity of poor farm households, the potential adverse effects of climate change on crop agriculture and food security will be increasing through time (Balew et al., 2014), as Ethiopia has also suffered from drought due to El Nino in 2015. This shows that for developing countries like Ethiopia, climate change threatens to deepen vulnerabilities, erode hard-won gains, and seriously undermine prospects for development (WDR, 2010).

Accordingly, assessing vulnerability provides a starting point for the determination of effective means of promoting remedial action, limiting impacts, supporting coping strategies and facilitating adaptation (Kelly and Adger, 2000); and can help answer where and how society best can invest to reduce vulnerability (Mearns and Norton, 2010). Moreover, effective planning for adaptation programming requires a fine-grained assessment of local vulnerabilities, practices and adaptation options and preferences (Kuriakose et al., 2009). To this end, some studies (Tadesse et al., 2008; Gebremichael and Kifle, 2009; Bewket, 2012; Tesso et al., 2012; Simane et al., 2013; Simane et al., 2014; Teshome, 2014) have been done in Ethiopia.

However, though most of the droughts occurred in the northeastern Ethiopia and the areas are more vulnerable to climate change impacts recently also suffering from drought due to El Nino in 2015/16; adaptation strategies practiced in the study areas, their appropriateness to create climate resilient households/agro-ecosystems, and the determinants of these adaptation strategies to practice them are not well addressed as there are gaps in the study areas covered, unit of analysis employed and the methodologies applied. As to the study areas covered, Tesso et al. (2012) studied econometric analysis of local level perception, adaptation and coping strategies to climate change induced shocks in North Shewa, Ethiopia, taking highland, midland and lowland agro-ecologies within the same livelihood system, but not agro-ecosystems of northeastern Ethiopia with different livelihood strategies. Bewket (2012) has assessed climate change perceptions and adaptive responses of smallholder farmers in central highlands of Ethiopia but not by comparing with lowland smallholder farmers, agro-pastoralists and pastoralists. Moreover, even in those few studies (Hadgu et al., 2015; Deressa, 2010) done in drought prone areas of northeastern Ethiopia, there are gaps in the unit of analysis employed not addressing agro-ecosystems and households in those agroecosystems. For instance, a study conducted by Tadesse (2010) has assessed vulnerability to climate change and adaptation responses using region as a unit of analysis in which, within the region there is a great variation from one agro-ecosystem to the other. Furthermore, there are gaps in the methodology applied in some of those studies. Gebremichael and Kifle (2009) have assessed adaptation strategies using qualitative methods only. However, both qualitative and quantitative approaches have their own strengths and weaknesses.

The purpose of this research, therefore, is to study households adaptation strategies to climate change and their determinants in highland and lowland mixed farming, agro-pastoral and pastoral agro-ecosystems/households in drought prone areas of northeastern Ethiopia to develop/design appropriate adaptation strategies that increase the resilience of agro-ecosystems/households. In so doing, the study aims at describing different adaptation strategies and analyzing their determinants mainly demographic variables, livelihood capitals, technology adoptions, institutional factors, and environmental factors.

\section{METHODOLOGY \\ Description of the Study Sites}

The study is conducted in Kobo and Golina, two bordering districts, in the Amhara and Afar regions respectively in the northeastern part of Ethiopia representing different agro-ecosystems. Agro-ecosystems mainly consist of agro-ecology and farming systems. Ethiopia has five traditional agro-ecological zones: bereha (desert, below 500 m.a.s.1.), kola (lowland, 500 to 1500 m.a.s.1.), weynadega (middle land, 1500 to 2500 m.a.s.1.), dega (highland, 2500 to 3500 m.a.s.1.), and Wurch (above 3500 m.a.s.1.) (MOA, 2000). The study districts fall in three of them (kola, weynadega and dega). Kobo is classified as highland/midland and lowland with an altitude ranging from 1000 to 3000 m.a.s.1. (Woreda Agricultural Development Office, 2013); and received an average annual rainfall of $750 \mathrm{~mm}$ and mean annual maximum and minimum temperature of 25 and $12^{\circ} \mathrm{C}$, respectively (NMA, 2012). On the other hand, Golina district comprised of two major agro-ecological zones. A smaller portion lies in the desert with an elevation of less than $500 \mathrm{~m}$ while a greater portion lay in the lowland with elevation between 500 and $650 \mathrm{~m}$ (Woreda Pastoral Development Office, 2013). This study considers mainly the lowland part and characterized with mean annual maximum and minimum temperature of 37 and $22^{\circ} \mathrm{C}$, respectively and average annual rainfall of $200 \mathrm{~mm}$ (NMA, 2012). 
Figure 1: Map of the Study Sites

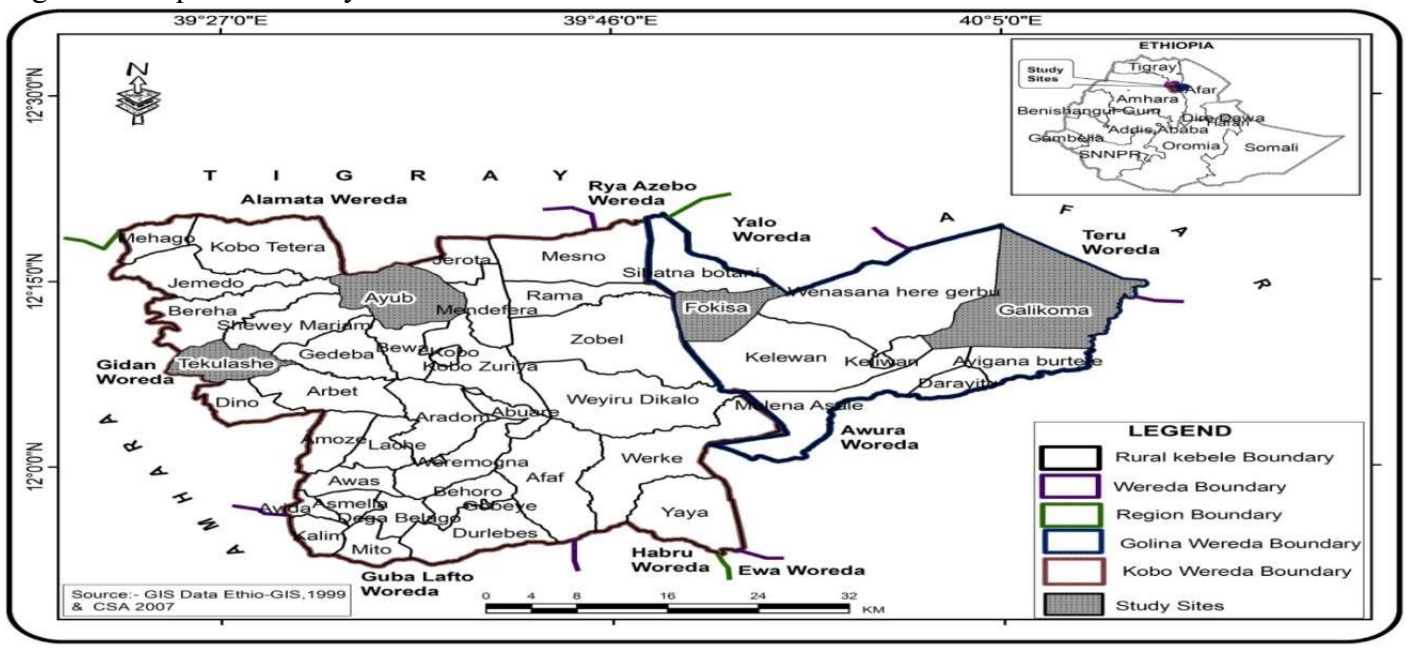

On the other hand, there are four major farming systems in Ethiopia: seed-farming, enset-planting, shifting cultivation, and pastoral complexes. The seed-farming complex focuses on grain production in the central, northern, and eastern highlands involving the majority of Ethiopian small farmers. Shifting cultivation and pastoral complexes are most common in the western and eastern lowlands, respectively (Westphal, 1975 cited in Chamberlin and Schmidt, 2011). Kobo district in the Amhara region is found in seed farming system (i.e., croplivestock mixed farming), characterized by various constraints mainly moisture scarcity due to rainfall variability, reduction of soil fertility, occurrence of crop pests and diseases, and shortage of farmland (Amhara Bureau of Agriculture, 2014). Golina district is found in pastoral farming system in Afar region. The Afar pastoralists pursue their livelihoods in subsistence based, mixed livestock management of camels, cattle, goats and sheep (PCDP, 2005). However, crop production is a newly emerging livelihood system in Golina district in Afar pastoral system. As a result, agro-pastoral farming system (crop production and livestock raising) is included in this study to get a complete picture of agro-ecosystem level analysis of climate change vulnerabilities in the study areas.

\section{Data Collection}

A combination of qualitative and quantitative research methods applied to overcome various weaknesses inherent in different methods (Dawson, 2009). Mixed research approach, therefore, employed to collect quantitative and qualitative data. Accordingly, household survey, observations, key informant interviews, focus group discussions, and secondary data analysis used iteratively to collect both primary and secondary data for this study. Temperature and rainfall station recorded data of the study areas and nearby stations from 1980 to 2010 obtained from National Meteorological Agency. Direct observation of the study sites conducted to look at the environmental, socioeconomic and institutional contexts. Key informant interviews conducted with representatives of Ministry of Environmental Protection and Forestry, Ministry of Agriculture, Ministry of Federal Affairs, Pastoralist Forum Ethiopia, and Climate Change Forum Ethiopia at the federal level. Moreover, representatives of different regional sectoral offices of Amhara and Afar regional states, local government officials and experts of the study districts, development agents of the study kebeles (the lowest administrative unit in Ethiopia), and households of both sexes at each agro-ecosystem interviewed. Fourteen focus group discussions ( 7 at each district) are conducted. The first FGD conducted with local government officials from different sectors (such as agriculture, environmental protection, water, health, education and women's affair) at district level to gather relevant information for both highland and lowland, and agro-pastoral and pastoral agro-ecosystems. Then, three FGDs conducted with local community workers (development agents, teachers and health extension workers), male households and female households for each agro-ecosystem.

The study districts were selected purposively to compare climate change vulnerability and adaptation of agroecosystems/households being found in drought prone areas and bordering each other. As it can be recalled from the description of the study sites section, the study areas are stratified by agro-ecosystem: highland mixed farming, lowland mixed farming, agro-pastoral, and pastoral areas. Then, since both districts have more or less proportional number of rural kebeles by agro-ecosystem, one rural kebele, representing each agro-ecosystem selected randomly. Finally, households selected using systematic sampling technique proportionately.

The study has employed the following formula to determine the sample size (Lohr, 2010). Accordingly, to obtain absolute precision $\mathrm{e}$, find the value of $\mathrm{n}$ that satisfies: 
To solve this equation for $\mathrm{n}$, first find the sample size $n_{0}$

$$
e=z \alpha / 2 \sqrt{\left(1-\frac{n}{N}\right) \frac{S}{\sqrt{n}}}
$$

Where $n=$ required sample size

$$
\begin{gathered}
n_{0}=\left(\frac{z \alpha / 2}{e}\right)^{2}, \text { then } \\
n=\frac{n_{0}}{1+\frac{n_{0}}{N}} \\
n=\frac{z_{\alpha}^{2} / 2 S^{2}}{e^{2}+\frac{z_{\alpha}^{2} / 2}{N} S^{2}}
\end{gathered}
$$

$z_{\alpha / 2}^{2}=1.96^{2}$

$N=$ the population size $=4530$

$S^{2} \approx P(1-p)$, which attains its maximum value when $\mathrm{p}=1 / 2$

$e=$ marginal error, usually for many surveys using a proportion, $\mathrm{e}=0.03$

$\alpha=$ level of significance, usually for many surveys using a proportion, $\alpha=0.05$

Finally, $n_{0}=\frac{(1.96)^{2}\left(\frac{1}{2}\right)\left(1-\frac{1}{2}\right)}{(0.03)^{2}} \approx 1067$

$$
n=\frac{n_{0}}{1+\frac{n_{0}}{N}}=\frac{1067}{1+\frac{1067}{4530}}=864
$$

Lohr (2010) has also pointed out that the final decision to set the sample size is up to the researcher based on the existing situation. More specifically, the same source has indicated that though the larger the sample the smaller is the sampling error, some adjustments can be done to reduce non-sampling error, based on the availability of the budget, and to control selection and measurement bias (Lohr, 2010). Accordingly, the sample size for this study adjusted to 432 due to the aforementioned factors.

Accordingly, as presented in Table 1, a total sample size of 432 households (169 from highland mixed

\begin{tabular}{|c|c|c|c|c|c|c|}
\hline Region & Zone & District & Agro-ecosystem & Rural kebele & No of $H H s^{*}$ & No of selected $\mathrm{HHS}$ \\
\hline \multirow[t]{2}{*}{ Amhara } & \multirow{2}{*}{$\begin{array}{l}\text { North } \\
\text { Wollo }\end{array}$} & \multirow[t]{2}{*}{ Kobo } & Highland Mixed Farming & Tekulashe & 1769 & 169 \\
\hline & & & Lowland Mixed Farming & Ayub & 1899 & 181 \\
\hline \multirow[t]{2}{*}{ Afar } & \multirow[t]{2}{*}{ Zone 4} & \multirow[t]{2}{*}{ Golina } & Agro-pastoral & Fokisa & 513 & 49 \\
\hline & & & Pastoral & Galikoma & 349 & 33 \\
\hline \multicolumn{2}{|c|}{ Total } & 2 & 4 & 4 & 4530 & 432 \\
\hline
\end{tabular}
farming, 181 from lowland mixed farming, 49 from agro-pastoral, and 33 from pastoral agro-ecosystems) are included in the survey using stratified proportionate sampling formula.

$$
\begin{gathered}
\text { Total sample } n=n_{1}+n_{2}+\cdots+n_{k} \\
n=\left(\frac{1769}{4530}(432)+\frac{1899}{4530}(432)+\frac{513}{4530}(432)+\frac{349}{4530}(432)\right) \\
\mathbf{n}=\mathbf{1 6 9}+\mathbf{1 8 1}+\mathbf{4 9}+\mathbf{3 3}=\mathbf{4 3 2}
\end{gathered}
$$

Table 1: Sampling Distribution

* Source: Respective Agricultural/Pastoral Development Offices, 2013

However, from 432 questionnaires, 6 of them were not included in the analysis due to various problems. Accordingly, a total sample size of 426 households (165 from highland mixed farming, 180 from lowland mixed farming, 48 from agro-pastoral, and 33 from pastoral agro-ecosystems) are included in the analysis.

\section{Modeling and Data Analysis}

Analytical Model

Discrete choice models are applied to analyze households' choice of adaptation strategies. Hence, the decision of whether or not to use any adaptation option could fall under the general framework of utility and profit maximization. For instance, consider a rational farmer and pastoralist who seek to maximize the present value of expected benefits of production over a specified time horizon, and their choice among a set of $J$ adaptation options. Then, the linear random utility model of a household's utility for two choices denoted by $U_{j}$ and $U_{k}$ specified as:

$$
U_{j}=\beta_{j}^{\prime} X_{i}+\varepsilon_{j} \text { and } U_{k}=\beta_{k}^{\prime} X_{i}+\varepsilon_{k} \ldots . \text { (1) }
$$

where $U_{j}$ and $U_{k}$ are perceived utilities of adaptation methods $j$ and $k$, respectively, $X_{i}$ is the vector of 
explanatory variables that influence the perceived desirability of the method, $\beta_{j}$ and $\beta_{k}$ are parameters to be estimated, and $\varepsilon_{j}$ and $\varepsilon_{k}$ are error terms assumed to be independently and identically distributed (Green, 2003).

Accordingly, the farmer/pastoralist $i$ decide to use $j$ adaptation option if the perceived benefit from option $j$ is greater than the utility from other $k$ options; depicted as

$$
U_{i j}\left(\beta_{j}^{\prime} X_{i}+\varepsilon_{j}\right)>U_{i k}\left(\beta_{k}^{\prime} X_{i}+\varepsilon_{k}\right), k \neq j \ldots(2)
$$

where $U_{i j}$ and $U_{i k}$ are the perceived utility by farmer/pastoralist $i$ of adaptation options $j$ and $k$, respectively; $X_{i}$ is a vector of explanatory variables that influence the choice of the adaptation option; $\beta_{j}$ and $\beta_{k}$ are parameters to be estimated; and $\varepsilon_{j}$ and $\varepsilon_{k}$ are the error terms.

Under the revealed preference, the assumption is that farmers/pastoralists practice an adaptation option that generates net benefits and does not practice an adaptation option otherwise. Then the observable discrete choice of practice can be related to the unobservable (latent) continuous net benefit variable as $Y_{i j}=1$ if $U_{i j}>0$ and $Y_{i j}=$ 0 if $U_{i j}<0$. In this formulation, $\mathrm{Y}$ is a dichotomous dependent variable taking the value of 1 when the farmer/pastoralist chooses an adaptation option in question and 0 otherwise.

The probability that farmer/pastoralist $i$ will choose adaptation option $j$ among the set of adaptation options defined as follows:

$$
\begin{aligned}
& P(Y=1 \mid X)=P\left(U_{i j}>U_{i k} \mid X\right) \ldots . \\
= & P\left(\beta_{j}^{\prime} X_{i}+\varepsilon_{j}-\beta_{k}^{\prime} X_{i}-\varepsilon_{k}>0 \mid X\right) \\
= & P\left(\left(\beta_{j}^{\prime}-\beta_{k}^{\prime}\right) X_{i}+\varepsilon_{j}-\varepsilon_{k}>0 \mid X\right) \\
= & P\left(\beta_{j}^{*} X_{i}+\varepsilon^{*}>0 \mid X\right)=F\left(\beta_{j}^{*} X_{i}\right),
\end{aligned}
$$

Where $\varepsilon^{*}$ is a random disturbance term, $\beta^{*}$ is a vector of unknown parameters that can be interpreted as the net influence of the vector of explanatory variables influencing adaptation, and $\mathrm{F}\left(\beta^{*} X_{i}\right)$ is the cumulative distribution of $\varepsilon^{*}$ evaluated at $\beta^{*} X_{i}$. Depending on the assumed distribution that the random term follows, several qualitative choice models such as a linear probability, logit, or probit model could be estimated (Greene, 2003). The logit and probit models are the most common models used in the literature. Indeed, they have desirable statistical properties as the probabilities are bound between 0 and 1 (Greene, 2003).

In this study, given that it is possible to investigate several adaptation choices, the appropriate econometric model would be either a multinomial logit (MNL) or multinomial probit (MNP) regression model. Both models estimate the effect of explanatory variables on a dependent variable involving multiple choices with unordered response categories. However, in this study, a MNL specification adopted to model households' choice of adaptation strategies involving discrete dependent variables with multiple choices. Thus, the probability that household i with characteristics $\mathrm{X}$ chooses adaptation option $\mathrm{j}$ specified as follows:

$$
\begin{gathered}
P_{i j}=\operatorname{Prob}(Y=1) \ldots . \\
=\frac{e^{X^{\prime \beta}}}{1+\sum_{j=1}^{j} e^{X^{\prime \beta}}} \quad, \mathrm{j}=1 \ldots . \mathrm{j},
\end{gathered}
$$

Where, $\beta$ is a vector of parameters that satisfy $\ln =\left(P_{i j} / P_{i k}\right)=X^{\prime}\left(\beta_{j}-\beta_{k}\right)$ (Greene, 2003).

Unbiased and consistent parameters estimates of the MNL model in Equation 4 require the assumption of independence of irrelevant alternatives (IIA) to hold. Specifically, the IIA assumption requires that the likelihood of a household's using a certain adaptation measure needs to be independent of other alternative adaptive measures used by the same household. Thus, the IIA assumption involves the independence and homoscedastic disturbance terms of the adaptation model in Equation 2. The validity of the IIA assumption tested using Hausman's specification, arguing that if a choice set is irrelevant, eliminating a choice or choice sets from the model altogether will not change parameter estimates systematically.

The parameter estimates of the MNL model provide only the direction of the effect of the independent variables on the dependent (response) variable, but estimates do not represent the actual magnitude of change or probabilities. Differentiating Equation 3 with respect to each explanatory variable provides marginal effects of the explanatory variables given as

$$
\frac{\partial P_{i}}{\partial X_{k}}=P_{j}\left(\beta_{j k}-\sum_{j=1}^{j} P_{j} \beta_{j k}\right)
$$

The marginal effects or marginal probabilities are functions of the probability itself and measure the expected change in probability of a particular choice being made with respect to a unit change in an independent variable from the mean (Green, 2003).

\section{Empirical Model for the Study}

Where, ASC - Adaptive strategy choice

$$
\mathrm{ASC}=\alpha_{0}+\alpha_{1} \mathrm{HDC}+\alpha_{2} \mathrm{ALC}+\alpha_{3} \mathrm{IF}+\alpha_{4} \mathrm{EF}+\varepsilon
$$

HDC - Household demographic characteristics

ALC - Access to livelihood capitals 


$$
\begin{aligned}
& \text { IF - Institutional factors } \\
& \text { EF - Environmental factors } \\
& \mathcal{E}-\text { Error term }
\end{aligned}
$$

\section{Data Analysis}

The survey data edited, coded and entered into a computer, and then analyzed using SPSS and STATA soft-wares as they do have differentiated qualities in data management and regression analysis respectively. Primarily, descriptive analysis [mainly percentage] done to present data/information in a manageable and understandable form. Subsequently, inferential analysis performed through principal component analysis model to examine climate change vulnerability of agro-ecosystems. On the other hand, the qualitative data gathered through observations, key informant interviews, and focus group discussions are analyzed using content analysis by moving deeper and deeper into understanding the data (Creswell, 2009). Finally, the obtained indexes of different agro-ecosystems explained using relevant indicators and qualitative findings from key informants, focus group discussion participants, and observations.

\section{Description of Model Variables}

The model variables for this study are categorized by exposure, sensitivity, and adaptive capacity (Table 2). The household's adaptive capacity constitutes demographic characteristics, livelihood strategy, livelihood capitals, access and use of modern technology, and institutions hypothesized to influence households' vulnerability in drought prone areas of northeastern Ethiopia. The sensitivity and exposure constitutes environmental and related

\begin{tabular}{|c|c|c|c|}
\hline Variable & Description & Value & $\begin{array}{l}\text { Expected } \\
\text { sign }\end{array}$ \\
\hline \multicolumn{4}{|c|}{ Household demographic characteristics } \\
\hline Gender & Gender of the household head & $\begin{array}{l}1=\text { male, } \quad 0= \\
\text { female }\end{array}$ & + or - \\
\hline Age & Age of the household head & Years & + or - \\
\hline Marital status & If household is married and 0 otherwise & $1=$ yes, $0=$ no & Positive \\
\hline Family planning methods & $\begin{array}{l}\text { If household uses family planning methods and } 0 \\
\text { otherwise }\end{array}$ & $1=$ yes, $0=$ no & Positive \\
\hline Household size & Number of family members of a household & Number & + or - \\
\hline Number of dependents & Number of dependents in a household & Number & + or - \\
\hline \multicolumn{4}{|c|}{ Household socioeconomic characteristics } \\
\hline Education & If household attend formal education and 0 otherwise & $1=$ yes, $0=$ no & Positive \\
\hline Adult education & $\begin{array}{l}\text { If household participate in adult education and } 0 \\
\text { otherwise }\end{array}$ & $1=$ yes, $0=$ no & Positive \\
\hline Farming experience & $\begin{array}{l}\text { Number of years of farming experience for the } \\
\text { household head }\end{array}$ & Years & Positive \\
\hline Access to information & $\begin{array}{l}\text { If household has access to information and } 0 \\
\text { otherwise }\end{array}$ & $1=$ yes, $0=$ no & Positive \\
\hline Health status & If household is healthy and 0 otherwise & $1=$ yes, $0=$ no & Positive \\
\hline Social networks & If household has social networks and 0 otherwise & $1=$ yes, $0=$ no & Positive \\
\hline Institutional membership & $\begin{array}{l}\text { If household has institutional membership and } 0 \\
\text { otherwise }\end{array}$ & $1=$ yes, $0=$ no & Positive \\
\hline Land ownership & Number of timads owned by the household & Timads & Positive \\
\hline $\begin{array}{l}\text { Water access for } \\
\text { irrigation }\end{array}$ & $\begin{array}{l}\text { If household has water access for irrigation and } 0 \\
\text { otherwise }\end{array}$ & $1=$ yes, $0=$ no & Positive \\
\hline $\begin{array}{l}\text { Walking distance to the } \\
\text { vicinity road }\end{array}$ & $\begin{array}{l}\text { Number of hours taken by the household to reach the } \\
\text { vicinity all weather road }\end{array}$ & Hours & Positive \\
\hline $\begin{array}{l}\text { Walking distance to the } \\
\text { nearest market place }\end{array}$ & $\begin{array}{l}\text { Number of hours taken by the household to reach the } \\
\text { nearest market place }\end{array}$ & Hours & Positive \\
\hline Access to clean water & If household has clean water access and 0 otherwise & & \\
\hline Mobile phone possession & If household has mobile phone and 0 otherwise & $1=$ yes, $0=$ no & Positive \\
\hline Saving & If household is saving and 0 otherwise & $1=$ yes, $0=$ no & Positive \\
\hline Credit taking & If household has taken credit and 0 otherwise & $1=$ yes, $0=$ no & Positive \\
\hline Livestock ownership & Amount of TLU owned by the household & TLU & Positive \\
\hline $\begin{array}{l}\text { Having non-agricultural } \\
\text { income }\end{array}$ & $\begin{array}{l}\text { If household has non-agricultural income and } 0 \\
\text { otherwise }\end{array}$ & $1=$ yes, $0=$ no & Positive \\
\hline
\end{tabular}
factors.

Table 2: Variables hypothesized influencing households' adaptation options 


\begin{tabular}{|c|c|c|c|}
\hline \multicolumn{4}{|c|}{ Institutional factors } \\
\hline $\begin{array}{l}\text { Agricultural/pastoral } \\
\text { extension services }\end{array}$ & $\begin{array}{l}\text { If household has access to agricultural /pastoral } \\
\text { extension services }\end{array}$ & $1=$ yes, $0=$ no & Positive \\
\hline $\begin{array}{l}\text { Access to credit } \\
\text { institution }\end{array}$ & $\begin{array}{l}\text { If household has access to credit institution and } 0 \\
\text { otherwise }\end{array}$ & $1=$ yes, $0=$ no & Positive \\
\hline Market place access & $\begin{array}{l}\text { Number of hours taken by the household to reach the } \\
\text { vicinity market place }\end{array}$ & Hours & Positive \\
\hline Education access & $\begin{array}{l}\text { Number of hours taken by the household to reach the } \\
\text { nearest primary school }\end{array}$ & Hours & Positive \\
\hline Health access & $\begin{array}{l}\text { Number of hours taken by the household to reach the } \\
\text { nearest health post }\end{array}$ & Hours & Positive \\
\hline \multicolumn{4}{|c|}{ Environmental factors } \\
\hline Temperature & $\begin{array}{l}1 \text { if a household perceive temperature increase and } 0 \\
\text { otherwise }\end{array}$ & Percentage & Positive \\
\hline Rainfall & $\begin{array}{l}1 \text { if a household perceive rainfall decrease and } 0 \\
\text { otherwise }\end{array}$ & Percentage & + or - \\
\hline $\begin{array}{l}\text { Drought occurrence } \\
\text { frequency }\end{array}$ & Drought occurrence frequency & Years & Positive \\
\hline Crop failure & 1 if a household face crop failure and 0 otherwise & $1=$ yes, $0=$ no & Negative \\
\hline Livestock death & 1 if a household face livestock death and 0 otherwise & $1=$ yes, $0=$ no & Negative \\
\hline Water scarcity & 1 if a household face water scarcity and 0 otherwise & $1=$ yes, $0=$ no & Negative \\
\hline Food shortage & $\begin{array}{l}1 \text { if a household face food shortage for } 3 \text { months and } \\
\text { above and } 0 \text { otherwise }\end{array}$ & $1=$ yes, $0=$ no & Negative \\
\hline Conflict & 1 if a household face conflict and 0 otherwise & $1=$ yes, $0=$ no & Negative \\
\hline
\end{tabular}

\section{RESULTS AND DISCUSSIONS}

\section{Adaptation Strategies}

Adaptation measures like soil and water conservation, water harvesting, changing crop types or varieties, changing planting date, crop diversification, irrigation, changing livestock types/breeds, livestock diversification, livelihood diversification, and migration/mobility are practiced in the studied agro-ecosystems.

\section{Soil and Water Conservation}

Table 3 shows that 64.8 and 55 percent of households in highland and lowland mixed farming agro-ecosystems respectively practice soil and water conservation as adaptation to climate change. Studies conducted by Hadgu et al. (2015), Legesse et al. (2013) and Mengistu (2011) have also indicated that farm households used it as adaptation options. Key informants and focus group discussion participants from these agro-ecosystems pointed out that local households have benefitted from such works through claiming degraded lands, improving soil fertility at farm level, improving crop productivity, getting fodder for livestock, and being resilient to drought (Figure 2). This is a good response as previous studies confirmed that the productivity of farmlands/rangelands deteriorated by various factors like traditional farming, overgrazing and deforestation, poor complementary services such as extension and credit, and climatic factors such as drought and flood (Tizale, 2007; Devereux, 2000).

Figure 2: Soil and Water Conservation in Tekulashe Kebele, Kobo district

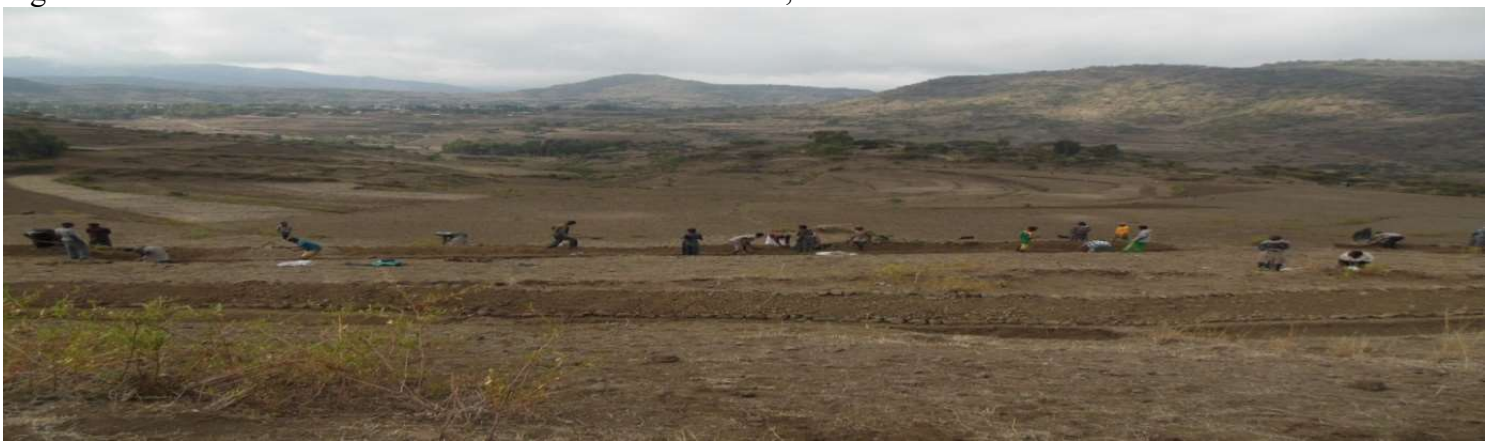

Source: Author, 2014

\section{Water Harvesting}

Table 3 also shows that 53.9, 53.9, 48.6 and 50.3 percent of households in highland mixed farming, lowland mixed farming, agro-pastoral, and pastoral agro-ecosystems harvest water respectively. However, key informants and 
focus group discussion participants indicated that households preoccupied by temporary benefits are selling the geo-membrane to others with low price, which they took from the government with the intention of construction of water harvesting structures. Despite this fact, informants and participants indicated that households who harvested water benefitted from it using for their livestock and small irrigation (Figure 3). Similarly, Bewket (2009) pointed out that rainwater harvesting and buffering at times of rainfall scarcity through the application of supplemental or protective irrigation might be a good option to protect loss of crop yields, or even complete crop failure.

Figure 3: Water harvesting in Ayub Kebele, Kobo district

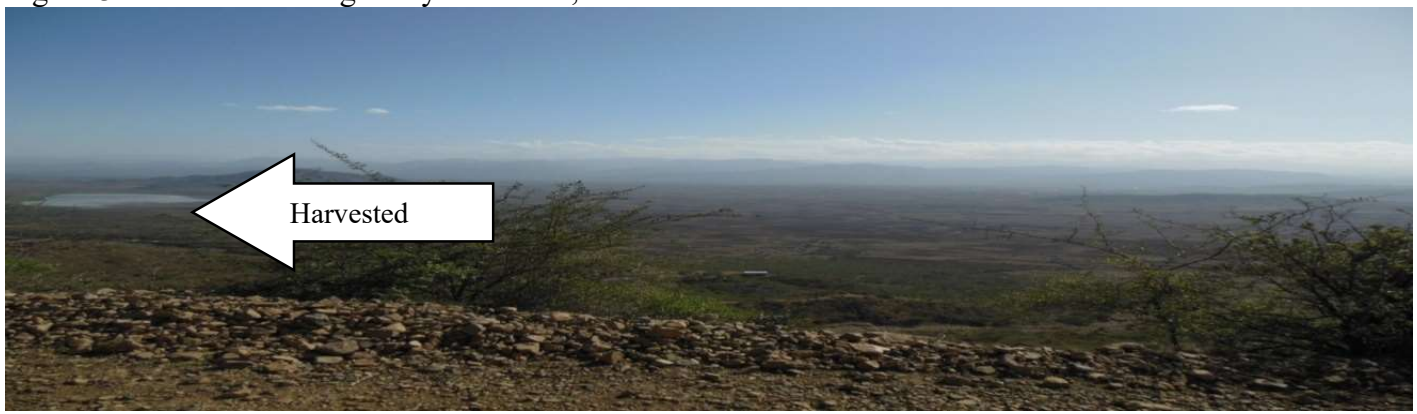

Source: Author, 2014

\section{Changing Crop Type and Variety}

As it can be seen from Table 3, 52.7 and 55 percent of households in highland and lowland mixed farming agroecosystems respectively change either crop type or variety as adaptation option. Previously conducted studies by Hadgu et al. (2015) and Mengistu (2011) have also indicated that farm households used changing crop type/variety as adaptation options. Consequently, key informants and focus group discussion participants from highland and lowland mixed farming agro-ecosystems indicated that households have benefitted in reducing crop failure, reducing crop pests and diseases, improving crop productivity, improving food security, and being resilient to drought by changing either crop type or variety. For instance, households change from being maize producer to sorghum producer especially at the highland mixed farming agro-ecosystem to improve their benefits.

Table 3: Households Climate Change Adaptation Strategies by Agro-ecosystem

\begin{tabular}{|c|c|c|c|c|}
\hline \multirow[t]{2}{*}{ Adaptation strategies } & \multicolumn{4}{|c|}{ Percentage of households practicing the strategies in agro-ecosystems } \\
\hline & $\begin{array}{l}\text { Highland mixed } \\
\text { farming }\end{array}$ & $\begin{array}{l}\text { Lowland mixed } \\
\text { farming }\end{array}$ & Agro-pastoral & Pastoral \\
\hline Soil and water conservation & 64.8 & 55 & 0 & 0 \\
\hline Water harvesting & 53.9 & 53.9 & 48.6 & 50.3 \\
\hline Change crop type/variety & 52.7 & 55 & 0 & 0 \\
\hline Changing planting date & 57 & 47.8 & 0 & 0 \\
\hline Crop diversification & 63 & 47.8 & 0 & 0 \\
\hline Practicing Irrigation & 46.7 & 52.2 & 0 & 0 \\
\hline Changing livestock type/breeds & 52.7 & 52.2 & 50 & 48.5 \\
\hline Livestock diversification & 52.7 & 52.8 & 54.9 & 49.1 \\
\hline Livelihood diversification & 55.8 & 56.1 & 50.7 & 49.7 \\
\hline Migration/mobility & 49.1 & 50 & 60.4 & 52.7 \\
\hline
\end{tabular}

Source: Field Survey, 2014

\section{Changing Planting Date}

As shown in Table 3, 57 and 47.8 percent of households in highland and lowland mixed farming agro-ecosystems respectively have changed the planting date. Similarly, Hadgu et al. (2015) and Mengistu (2011) have also indicated that farm households used changing planting date as adaptation options. As a result, key informants and focus group discussion participants from highland and lowland mixed farming agro-ecosystems indicated that households have changed their planting date from the usual date of planting practiced by their parents/grandparents to a suitable time based on the starting date of the rainfall.

\section{Crop Diversification}

As indicated in Table 3, 63 and 47.8 percent of households in highland and lowland mixed farming agroecosystems respectively practiced crop diversification. Previously conducted studies by Hadgu et al. (2015) and Legesse et al. (2013) have also indicated that farm households used crop diversification as adaptation options. As a result, key informants and focus group discussion participants from highland and lowland mixed farming agro- 
ecosystems indicated that households have planted both early and lately maturing crops not to be a complete loser from the variable rainfall. For instance, a household in the lowland agro-ecosystem planted maize, sorghum, teff, and chickpea.

\section{Irrigation}

Moreover, Table 3 shows that 46.7 and 52.2 percent of households in highland and lowland mixed farming agroecosystem practiced irrigation. Studies conducted by Hadgu et al. (2015), Mengistu (2011) and Deressa et al. (2009) have also indicated that farm households used irrigation practices as adaptation options. In so doing, key informants and focus group discussion participants from highland and lowland mixed farming agro-ecosystems has indicated that households who are practicing furrow irrigation through river diversion or ground water have benefitted in reducing crop failure, improving crop productivity, improving food security, and being resilient to drought (Figure 4).

Figure 4: Irrigation schemes in highland and lowland mixed farming agro-ecosystems

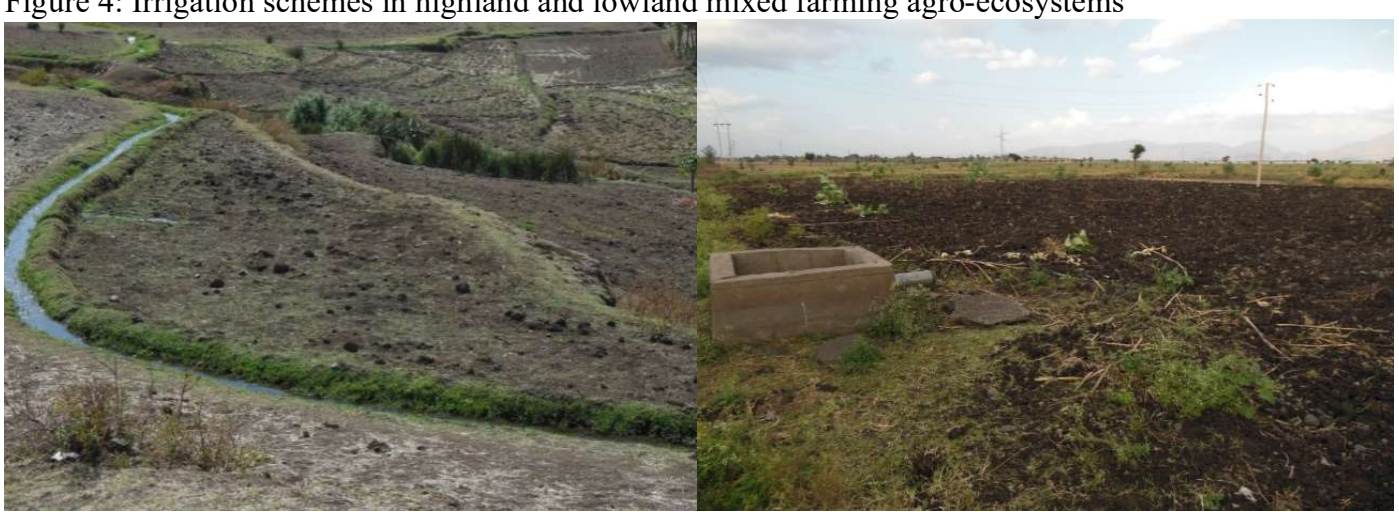

Source: Author, 2014

\section{Changing Livestock Type and Breeds}

Furthermore, Table 3 shows that 52.7, 52.2, 50 and 48.5 percent of households in highland mixed farming, lowland mixed farming, agro-pastoral, and pastoral agro-ecosystems respectively changed either livestock type or breeds. In line with this, a study conducted by Gebremichael and Kifle (2009) indicated that pastoralists adapt to climate change through selection of livestock species (shifting from cattle towards goats and camels). To this end, key informants and focus group discussion participants from highland and lowland mixed farming agro-ecosystems indicated that households have benefitted in reducing livestock diseases, improving livestock productivity, improving food security, and being resilient to drought. However, key informants and focus group discussion participants from agro-pastoral and pastoral agro-ecosystems indicated that households in their agro-ecosystem are not practicing well such adaptation strategies as they give high value to cattle.

\section{Livestock Diversification}

Table 3 also shows that 52.7, 52.8, 54.9 and 49.1 percent of households in highland mixed farming, lowland mixed farming, agro-pastoral and pastoral agro-ecosystems practiced livestock diversification. Accordingly, key informants and focus group discussion participants indicated that households have benefitted in reducing livestock diseases, improving livestock productivity, improving food security, and being resilient to drought. Thus, informants and participants from agro-pastoral and pastoral agro-ecosystems have added that most households are rearing cattle, camel, goats and sheep which are grazers and browsers to adapt to the scarcity of pasture resulted from drought.

\section{Diversification of Livelihood Strategies}

Table 3 shows that 55.8, 56.1, 50.7 and 49.7 percent of households in highland mixed farming, lowland mixed farming, agro-pastoral, and pastoral agro-ecosystems respectively are diversifying their livelihood strategies. A study conducted by Yizengaw et al. (2015) indicated that smallholder farm households use different livelihood strategies: on-farm, non-farm, and off-farm activities. However, informants and participants argued that there should be market for various agricultural products. In relation to this, a study conducted by UN OCHA-PCI (2007) indicated that the future of pastoralism in Ethiopia should be based on four scenarios: alternative livelihoods, sustaining pastoral livelihoods, added-value diversification, and expanding export trade. However, Bazezew et al. (2013) found that despite the low level of productivity related to local environmental constraints, rural livelihoods remain undiversified with small-scale rain-fed agriculture providing the primary source of livelihood for the large majority of households. 


\section{Migration/Mobility}

Finally, Table 3 shows that 49.1, 50.0, 60.4 and 52.7 percent of households in highland mixed farming, lowland mixed farming, agro-pastoral, and pastoral agro-ecosystems respectively are practicing migration/mobility. There are different types of migration/mobility. Some of these are temporary internal migration, permanent internal migration, and international migration. By so doing, key informants and focus group discussion participants have pointed out that there are different benefits such as increasing income, helping family, solving problem, getting employment opportunity, and learning. In the same way, key informants and focus group discussion participants have argued that many people are migrating due to various reasons like lack of farmland and lack of pasture and water in their locality. A study conducted by Gebru and Beyene (2012) indicated that migration is an important livelihood strategy and plays a crucial role both in the survival of the poor and as income accumulation as people in the area are suffering from both persistent and transitory food insecurity due to drought, war, landlessness and poor agricultural production and productivity.

In conclusion, there are different adaptation strategies practiced by different agro-ecosystems. A study conducted by Hisali et al. (2011) substantiates this stating there are differences in choice of adaptation strategies by agro-climatic zone. Similarly, studies conducted by Deressa et al. (2009), Tesso et al. (2012) and Legesse et al. (2013) also observed that farmers living in different agro-ecological settings have different choice of adaptation options. Moreover, a study conducted by van Ginkel et al. (2013) indicated that there are differences in choice of adaptation strategies by agro-ecosystems and livelihood strategies. Accordingly, determinants of adaptation options are discussed as follows:

\section{Determinants of Adaptation Options}

Multinomial logit model run using all determinants together for each agro-ecosystem taking 'no adaptation' as the base category to compare with the other adaptation strategies. The MNL model tested using the Hausman specification test to see the fulfillment of the independence of irrelevant alternatives (IIA) assumption. The Hausman test supported that IIA not violated with $\chi^{2}$ ranging from 7.8 up to 130.7 with probability values ranging from 0.286 to 0.923 showing that statistically not significant. Moreover, VIF calculated to see the problem of multicollinearity, and all VIF values are less than 10 (1.22 up to 4.34), indicating that it is safe to include the variables in the model.

Furthermore, parameter estimates of the MNL model provide only the direction of the effect of the independent variables on the dependent variables without showing actual magnitude of change or probabilities. Hence, the marginal effects from the MNL that measure the expected change in probability of a particular choice made with respect to a unit change in an independent variable is used to explain the choice of households for different adaptation options in different agro-ecosystems. The likelihood ratio statistics as indicated by $\chi^{2}$ statistics are highly significant $(P<0.00001)$ for all adaptation options in each agro-ecosystem, suggesting the model has a strong explanatory power (Table $4,5,6$, and 7 ).

\section{Gender}

Male-headedness increases significantly the probability of crop and livelihood diversification by 78.5 and 76.7 percent respectively in highland mixed farming agro-ecosystem (Table 4). Accordingly, key informants and focus group discussion participants have argued that female-headed households are more vulnerable. Likewise, Opiyo et al. (2014) indicated that female-headed households are highly vulnerable to climate change impacts. In lowland mixed farming agro-ecosystem, male-headed households increase significantly the probability of migration by 62.2 percent (Table 5). This is in line with a study conducted by Atinkut and Mebrat (2016) indicating that maleheaded households than female-headed ones practice seasonal migration. On the other hand, male-headed households increase significantly the probability of changing crop type/variety and changing livestock type/breeds by 75.2 and 40 percent respectively in lowland mixed farming agro-ecosystem (Table 5). Moreover, maleheadedness increases significantly the probability of livestock diversification and livelihood diversification by 71.8 and 84.3 percent respectively in agro-pastoral agro-ecosystem (Table 6). Furthermore, male-headedness increases significantly the probability of water harvesting, changing livestock type and breeds, livestock diversification, and livelihood diversification by $93.5,95.2,99.4$, and 99.2 percent respectively in pastoral agroecosystem (Table 7). This might be due to the fact that most male-headed households have camels in addition to other livestock. However, male-headedness decreases significantly the probability of mobility by 99.5 percent in agro-pastoral agro-ecosystem (Table 6) and by 95.1 percent in pastoral agro-ecosystem (Table 7). According to key informants, this is because of that women are very important persons for the households in accomplishing mobility related tasks except looking after camels.

\section{Age}

One-year increase in household head age increases the probability of irrigation and livelihood diversification by 3.9 and 12 percent respectively in highland mixed farming agro-ecosystem (Table 4). This is because that aged 
farmers might have better knowledge and technical skills to practice the options. Similarly, a study conducted by Hadgu et al. (2015) has indicated that one-year increase in the age of the household head significantly increases the probability of adopting crop type/variety, crop diversification, soil and water conservation, and irrigation practices. By contrast, one-year increase in household head age decreases the probability of changing crop type/variety and changing livestock type/breeds by 3.8 and 3.9 percent respectively (Table 4). A unit increase in age also decreases the probability of changing planting date, irrigation, changing livestock type/breeds, and livestock diversification by 4.5, 6.6, 3.9 and 7.9 percent respectively in lowland mixed farming agro-ecosystem (Table 5). This might be because of the labor demanding nature of the adaptation strategies. Mulatu (2013) has also asserted that an increase in the age of the household by one year decreases the probabilities of irrigation. In agro-pastoral agro-ecosystem, one-year increase in household head age increases significantly the probability of livelihood diversification and mobility by 58.9 and 30.9 percent respectively (Table 6 ). The former might be due to the fact that experienced pastoralists may have better skills in management of their resources like livestock. Deressa et al. (2008) also indicated that as age increases the probability of adapting to climate change increases. However, one-year increase in household head age decreases significantly the probability of changing livestock type/breeds by 32.3 percent (Table 6). The possible reason might be the rigidity of the households since they have attached some values to certain types of livestock like cattle and camels. Furthermore, a unit change in age also increases significantly the probability of livestock diversification, livelihood diversification, and mobility by 15.1 , 13.8 and 12.9 percent respectively in pastoral agro-ecosystem (Table 7). The probable reason is that age may enable households to make better assessment of the risks involved in practicing adaptation options.

\section{Marital Status}

Married households increase significantly the probability of livelihood diversification by 85.9 percent in highland mixed farming agro-ecosystem (Table 4). As it was observed, this is because of married households have better resource ownership such as land and livestock to diversify their livelihoods. Moreover, key informants and focus group discussion participants have argued that divorced/widowed households are not employing most adaptation measures, as they are labor demanding which in turn makes them more vulnerable. In relation to this, Kakota et al. (2011) in Malawi and Tesso et al. (2012) in Ethiopia have also made similar observations that widowed or divorced household heads are more vulnerable as they are not practicing labor-intensive livelihood strategies especially in rural areas. Alternatively, married households decrease significantly the probability of changing planting date and livestock diversification by 99.9 and 72.7 percent respectively in highland mixed farming agroecosystem (Table 4) and the probability of soil and water conservation, water harvesting, changing crop type and variety, crop diversification, and irrigation by $92.4,81.8,89.1,64.2$, and 70.3 percent respectively in lowland mixed farming agro-ecosystem (Table 5). This shows that marriage is decreasing the employment of most of the adaptation options as the female partner might be totally occupied by childcare in which not contributing to onfarm activities especially in the earlier stages of marriage. In lowland mixed farming agro-ecosystem, married households increase significantly the probability of changing livestock type and breeds by 44.2 percent (Table 5). This is because as households are married they are most likely to have children and these children are supporting their family in herding livestock and other activities. On the other hand, married households also decrease significantly the probability of migration by 96.1 percent in lowland mixed farming agro-ecosystem (Table 5). The probable reason might be that when households are married there will have less intent of migration to Arabic countries, which is widely practiced in the study areas. Married households in agro-pastoral agro-ecosystem increase significantly the probability of livelihood diversification and mobility by 88.1 and 62.7 percent respectively (Table 6). The possible reason might be that when households are married they do have better resources to diversify their livelihood strategies through crop production, livestock production, and off-farm/nonfarm activities. Conversely, married households decrease significantly the probability of livestock diversification by 66.2 percent (Table 6). This is because of that males are more likely to rear camels and cattle than diversifying with goats/sheep.

\section{Family Planning}

Use of family planning methods decrease significantly the probability of soil and water conservation, water harvesting, crop diversification, changing livestock type/breeds, and livestock diversification by 94.5, 44.8, 32.5, 90.9 and 61.2 percent respectively in highland mixed farming agro-ecosystem (Table 4). Moreover, using family planning methods decreases significantly the probability of water harvesting by 42.3 percent in lowland mixed farming agro-ecosystem (Table 5). Furthermore, use of family planning methods decrease significantly the probability of water harvesting, changing livestock type/breeds, livestock diversification, livelihood diversification and migration/mobility by $64.8,73,79.6,79.1$ and 61.7 percent respectively in pastoral agro-ecosystem (Table 6). The possible reason is that when households use family planning methods, they would have less number of children, which in turn decreases the availability of labor for practicing different adaptation options. Key informants and focus group discussion participants have argued that households who use family planning methods 
might not have large labor force. On the other hand, in lowland mixed farming agro-ecosystem, using family planning methods increases significantly the probability of changing plating date, irrigation and livelihood diversification by 33.3, 54.9 and 66 percent respectively (Table 5). The probable reason might be when households use family planning methods they will have time to accomplish different agricultural activities. In line with, a study conducted by Guzman et al. (2009) asserted that access to voluntary family planning services play a crucial role in the practice of adaptation strategies.

\section{Household Size}

A unit changes in household size increase significantly the probability of changing livestock type/breeds and livestock diversification by 88.4 and 57.5 percent respectively in highland mixed farming agro-ecosystem (Table 4). This might be due to the fact that large family is associated with higher labor endowment which would enable a household to accomplish various agricultural tasks especially at peak seasons. In relation to this, key informants and focus group discussion participants have argued that large family size can be an asset or a burden depending on their contribution to the family. Similarly, previous studies indicated that small household size creates labor constraints (Teklewold et al., 2006); and a household with many members forced to divert part of the labor force to off-farm activities to ease the consumption pressure (Tizale, 2007; Hassan and Nhemachena, 2008). On the other hand, a unit changes in household size decreases significantly the probability of livelihood diversification by 57.5 percent in highland mixed farming agro-ecosystem (Table 4). The possible reason might be it is not the household size that matters but the contribution of the members to support that family. Thus, if most of the household members of the large family were dependents they would be a liability to the households rather than an asset. On the other hand, a unit changes in household size in pastoral agro-ecosystem increase significantly the probability of livestock diversification by 48.6 percent (Table 7). As it was observed, households with large family size have a potential of using their children to look after different types of livestock. In line with this, a study conducted by Atinkut and Mebrat (2016) has indicated that households' who have larger family have an opportunity of pursuing various adaptation options in the face of climate variability.

\section{Number of Dependents}

A unit increases in dependents number decrease significantly the probability of livestock diversification by 61 percent in highland mixed farming agro-ecosystem (Table 4). As it is indicated while discussing household size, children can be an asset and a liability. If the children are not engaged into at least on looking for livestock, they are dependent and more importantly a liability for the household. Moreover, key informants and focus group discussion participants have also argued that households with large number of dependents in the household are not employing different adaptation measures particularly, which is labor-demanding. A study conducted by Opiyo et al. (2014) has indicated that households with high number of dependents are likely to be more vulnerable than households with fewer dependents. Moreover, a unit increases in dependents number increases significantly the probability of changing livestock type/breeds by 22.6 percent in lowland mixed farming agro-ecosystem (Table 5). This is due to the fact that when there are many dependents in the household, they are more likely to have different types of livestock as the dependents can look after those livestock. Conversely, a unit increases in dependents number decreases significantly the probability of crop diversification by 47.6 percent in lowland mixed farming agro-ecosystem (Table 5). As key informant stated, households with many dependents are less likely to practice crop diversification because of its high labor demand. A unit changes in dependents number increases significantly the probability of changing livestock type/breeds and livestock diversification by 42.5 and 95.1 percent respectively in agro-pastoral agro-ecosystem (Table 6). The probable reason might be some dependents could help their family in labor work like looking for livestock and some easily accomplished on-farm activities. By the contrary, a unit changes in dependents number decrease significantly the probability of mobility by 58.3 percent in agro-pastoral agro-ecosystem (Table 6). The probable reason may be dependents could not move independently with the family's livestock especially during water and pasture scarcity in their locality. Furthermore, a unit increases in dependents number decreases significantly the probability of changing livestock type/breeds and livestock diversification by 66.1 and 64.2 percent respectively in pastoral agro-ecosystem (Table 7). This is because some dependents could not help their family in labor work even looking for livestock. 
Table 4: Marginal effects of multinomial logistic regression model for determinants of adaptation options in Highland mixed farming agro-ecosystem

\begin{tabular}{|c|c|c|c|c|c|c|c|c|c|c|}
\hline $\begin{array}{l}\text { Explanatory } \\
\text { variables }\end{array}$ & $\begin{array}{l}\text { Soil \& water } \\
\text { conservation }\end{array}$ & $\begin{array}{c}\text { Water } \\
\text { harvesting }\end{array}$ & $\begin{array}{c}\text { Changing } \\
\text { crop } \\
\text { type/variety }\end{array}$ & $\begin{array}{c}\text { Changing } \\
\text { planting } \\
\text { date }\end{array}$ & $\begin{array}{c}\text { Crop } \\
\text { diversification }\end{array}$ & Irrigation & $\begin{array}{l}\text { Changing } \\
\text { livestock } \\
\text { type/breeds }\end{array}$ & $\begin{array}{c}\text { Livestock } \\
\text { diversification }\end{array}$ & $\begin{array}{c}\text { Livelihood } \\
\text { diversification }\end{array}$ & $\begin{array}{l}\text { Migration/ } \\
\text { mobility }\end{array}$ \\
\hline Gender & -0.335 & 0.087 & -0.029 & 0.019 & $0.785^{* * *}$ & 0.569 & -0.383 & -0.276 & $0.767^{* *}$ & -0.099 \\
\hline Age & -0.032 & -0.007 & $-0.038 * *$ & 0.001 & -0.005 & $0.030^{*}$ & $-0.039 *$ & -0.070 & $0.120^{* * *}$ & -0.008 \\
\hline Marital status & 0.189 & -0.048 & -0.568 & $-0.999 * * *$ & 0.238 & $\begin{array}{l}0.119 \\
-0.119\end{array}$ & $\begin{array}{l}-0.0518 \\
-0.518\end{array}$ & $\begin{array}{l}-0.0727 * * \\
-0.76\end{array}$ & $0.859 * * *$ & 0.127 \\
\hline Family planning & $-0.945 * * *$ & $-0.448 * *$ & -0.310 & 0.034 & $-0.325 *$ & -0.349 & $-0.909 * * *$ & $-0.612 * * *$ & -0.002 & -0.218 \\
\hline Household size & 0.104 & -0.004 & -0.111 & 0.121 & -0.002 & -0.206 & $0.884 * * *$ & $0.575^{*}$ & $-0.575^{*}$ & -0.009 \\
\hline $\begin{array}{l}\text { Number } \\
\text { dependents }\end{array}$ & 0.126 & -0.226 & 0.051 & -0.091 & -0.026 & 0.145 & -0.098 & $-0.610^{* * *}$ & 0.286 & 0.010 \\
\hline Formal education & 0.528 & -0.053 & $-0.685 * * *$ & -0.064 & $-0.460 * * *$ & -0.028 & -0.295 & 0.331 & -0.221 & $-0.413 * *$ \\
\hline Adult education & 0.412 & $-0.583^{* * *}$ & -0.108 & $0.812 * *$ & $-0.364 * * *$ & -0.184 & 0.169 & 0.146 & $-0.800 * * *$ & -0.165 \\
\hline $\begin{array}{l}\text { Access to } \\
\text { information }\end{array}$ & 0.188 & $0.463^{* *}$ & $0.797^{* * * *}$ & $0.999^{* * *}$ & -0.196 & 0.269 & -0.017 & -0.240 & 0.097 & -0.063 \\
\hline Farming experience & -0.008 & -0.037 & $0.057 * *$ & -0.016 & -0.012 & 0.023 & $-0.081^{* * * *}$ & 0.008 & -0.070 & -0.012 \\
\hline Health status & $0.869 * * *$ & 0.145 & $0.433^{*}$ & 0.032 & 0.151 & -0.013 & -0.309 & -0.309 & 0.251 & 0.081 \\
\hline Social networks & 0.110 & -0.167 & -0.321 & 0.019 & 0.124 & $0.694 * * *$ & -0.048 & $0.364 *$ & -0.031 & $0.520^{* * * *}$ \\
\hline $\begin{array}{l}\text { Institutional } \\
\text { membership }\end{array}$ & $0.143^{*}$ & -0.321 & $0.375^{* * *}$ & 0.016 & $0.235^{* * *}$ & -0.201 & $0.245^{* *}$ & 0.347 & $0.277^{*}$ & -0.116 \\
\hline $\begin{array}{l}\text { Land } \quad \text { ownership } \\
* * * *\end{array}$ & -0.136 & $0.453^{*}$ & $0.557^{* * *}$ & -0.152 & $0.470^{* * * *}$ & $0.970^{* * *}$ & -0.076 & $0.791 * *$ & -0.300 & -0.051 \\
\hline $\begin{array}{l}\text { Irrigation water } \\
\text { access }\end{array}$ & $0.892^{* * * *}$ & $0.387 * * *$ & -0.023 & $0.564^{*}$ & 0.079 & $0.505^{* * *}$ & -0.114 & $0.373^{*}$ & -0.150 & 0.085 \\
\hline Road distance & -0.096 & -0.348 & 0.011 & 0.266 & 0.151 & $-0.340 * *$ & $-0.989 *$ & -0.494 & 0.909 & 0.442 \\
\hline Market distance & -0.092 & 0.152 & -0.166 & 0.074 & 0.186 & -0.182 & 0.081 & 0.354 & $-0.477 *$ & -0.172 \\
\hline Clean water access & -0.541 & 0.031 & 0.045 & 0.144 & -0.004 & 0.164 & $0.402 *$ & -0.050 & $0.329^{*}$ & -0.021 \\
\hline Mobile phone & -0.206 & $0.437^{*}$ & 0.100 & 0.087 & -0.160 & -0.170 & -0.124 & 0.210 & $0.434 * *$ & 0.058 \\
\hline Saving & 0.022 & $0.468 * * *$ & $0.412 *$ & -0.110 & -0.179 & 0.215 & $0.771^{* * *}$ & 0.417 & $0.475 * * *$ & 0.051 \\
\hline Credit taking & 0.364 & $0.490^{* *}$ & -0.153 & 0.185 & 0.208 & -0.188 & 0.015 & $0.494^{*}$ & $0.457^{* *}$ & $0.314^{* *}$ \\
\hline $\begin{array}{l}\text { Livestock } \\
\text { ownership***** }\end{array}$ & -0.149 & 0.106 & 0.137 & 0.000 & 0.158 & 0.122 & $0.699^{* * * *}$ & $0.640^{* * * *}$ & -0.032 & 0.110 \\
\hline $\begin{array}{l}\text { Non-agricultural } \\
\text { income }\end{array}$ & -0.002 & -0.218 & 0.104 & 0.676 & -0.179 & 0.137 & $0.752^{* * *}$ & $-0.559 * *$ & $-0.564 * * *$ & 0.147 \\
\hline $\begin{array}{l}\text { Agricultural } \\
\text { extension }\end{array}$ & 0.158 & -0.348 & $0.631^{* * * *}$ & $0.982 * * *$ & 0.063 & $0.582 * * *$ & 0.213 & 0.038 & $0.636^{* * *}$ & $0.319^{*}$ \\
\hline $\begin{array}{l}\text { Access to credit } \\
\text { institution }\end{array}$ & -0.259 & -0.422 & -0.165 & -0.045 & -0.230 & $0.441^{* *}$ & $0.606 * * *$ & $0.718^{* * * *}$ & $0.704 * * *$ & -0.107 \\
\hline Market access & $0.937 * * *$ & $0.656 * * *$ & $0.678^{* * * *}$ & 0.038 & $0.275^{* * *}$ & $0.942 * * *$ & -0.345 & $0.792 * * *$ & $0.615 * * *$ & $0.547 * * *$ \\
\hline School distance & 0.551 & -0.266 & -0.163 & 0.236 & -0.322 & -0.261 & 0.377 & 0.344 & -0.067 & -0.104 \\
\hline Health post distance & -0.325 & 0.048 & -0.121 & -0.289 & -0.145 & -0.345 & $-0.465^{* * *}$ & -0.008 & 0.315 & 0.058 \\
\hline $\begin{array}{l}\text { Perception of temp. } \\
\text { increase }\end{array}$ & $0.995^{* * *}$ & $0.383^{* *}$ & $0.382 * *$ & 0.033 & 0.108 & -0.096 & 0.079 & -0.179 & $0.536 * * *$ & 0.175 \\
\hline $\begin{array}{l}\text { Perception of } \\
\text { Rainfall decrease }\end{array}$ & -0.704 & -0.069 & $0.509^{* *}$ & $0.915 * * *$ & $0.728^{* * * *}$ & -0.202 & $0.753^{* * *}$ & $0.632^{* * *}$ & -0.363 & $0.379 * *$ \\
\hline $\begin{array}{l}\text { Drought occurrence } \\
\text { frequency }\end{array}$ & -0.200 & -0.034 & 0.284 & -0.234 & -0.013 & -0.180 & -0.144 & $0.932^{* * * *}$ & -0.223 & -0.031 \\
\hline Crop failure & -0.352 & $0.474^{* * * *}$ & -0.221 & 0.132 & 0.154 & 0.415 & -0.097 & $0.424 *$ & 0.143 & $0.290 * *$ \\
\hline Livestock death & -0.717 *** & -0.118 & -0.178 & -0.402 & 0.161 & -0.110 & 0.195 & 0.134 & 0.018 & 0.147 \\
\hline Water scarcity & -0.172 & $0.349^{*}$ & -0.155 & -0.021 & 0.258 & 0.025 & -0.152 & 0.459 & 0.390 & -0.206 \\
\hline Food shortage & 0.129 & 0.279 & $0.557 * *$ & -0.100 & $0.797 * * *$ & -0.290 & $0.535^{* * *}$ & $0.865^{* * * *}$ & $0.789 * * *$ & $\begin{array}{l}-0.238 \\
-0.238\end{array}$ \\
\hline Conflict occurrence & 0.217 & -0.098 & 0.237 & 0.308 & $-0.219^{* *}$ & -0.122 & 0.058 & 0.237 & -0.122 & 0.026 \\
\hline Diagnostics & & & & & & & & & & \\
\hline Base category & & & & & No adaptation & & & & & \\
\hline $\begin{array}{l}\text { Number } \\
\text { observations }\end{array}$ & & & & & 165 & & & & & \\
\hline LR chi - square & 154.3 & 121.2 & 110.6 & 181.7 & 92.8 & 131.5 & 130.9 & 149.0 & 123.7 & 47.6 \\
\hline Log likelihood & -29.8 & -53.2 & -58.8 & -21.9 & -62.3 & -48.2 & -48.7 & -39.6 & -51.4 & -90.5 \\
\hline Pseudo R - square & 0.721 & 0.532 & 0.485 & 0.81 & 0.427 & 0.577 & 0.573 & 0.653 & 0.546 & 0.208 \\
\hline
\end{tabular}

Source: Field Survey, 2014

Note: $* * *$ significant at $1 \%, * *$ significant at $5 \%, *$ significant at $10 \%$

**** 4 timads are equal to 1 hectare

$* * * * *$ Tropical Livestock Unit (TLU) conversion factors: camel $=1$, cattle $=0.7$, horse $=0.8$, mule $=0.7$, donkey $=0.5$, sheep $/$ goat $=0.1$, chicken $=0.01$ (Source: FAO, 1987).

\section{Formal Education}

In highland mixed farming agro-ecosystem, attending formal education decreases significantly the probability of changing crop type/variety, crop diversification and migration by $68.5,46$ and 41.3 percent respectively (Table 4). Moreover, attending formal education decreases significantly the probability of water harvesting, irrigation, changing livestock type/breeds and migration by 77.4, 63.6, 41.1 and 83.7 percent respectively in lowland mixed farming agro-ecosystem (Table 5).This might be the time taking nature of attending education which competes the time given to on-farm activities. On the other hand, attending formal education increases significantly the probability of crop diversification by 73.2 percent in lowland mixed farming agro-ecosystem (Table 5). In agopastoral agro-ecosystem, attending formal education also increases significantly the probability of livelihood diversification and mobility by 73.8 and 93.6 percent respectively (Table 6). As it was observed and asserted by key informants, though attending formal education competes their time given for on-farm activities, after they gain the knowledge and the skills, educated households are performing well in improving their livelihoods. Balew et al. (2014) also found that households that have higher educational level had a better access to climate change information that in turn enhances their ability to adaptation. On the other hand, attending formal education decreases significantly the probability of changing livestock type/breeds and livestock diversification by 84.3 and 78.2 percent respectively (Table 6). The possible reason might be when household heads or members of a household attend formal education it affects the time given to diversify their livestock and move from place to place in search of pasture and water especially during drought. Furthermore, attending formal education decreases significantly the probability of water harvesting, changing livestock type/breeds, livestock diversification, 
livelihood diversification, and mobility by $75.2,76.9,83.9,83.9$ and 71.1 percent respectively in pastoral agroecosystem (Table 7). This might be due to the fact that formal educations are offered mostly in the regular program while most of the pastoralists are mobile which in turn affects their responsive capacity to climate change impacts using various adaptation options like mobility.

\section{Adult Education}

In highland mixed farming agro-ecosystem, participating in adult education increases significantly the probability of changing planting date by 81.2 percent (Table 4). Moreover, participating in adult education increases significantly the probability of soil and water conservation by 65.6 percent in lowland mixed farming agoecosystem (Table 5). This is due to the fact that when households attend adult education they are more likely to get access for early warning information through various mechanisms. Moreover, as it was observed and asserted by key informants, attending adult education competes their time given for on-farm activities, however, after they gain the knowledge and the skills, educated households are performing well in improving their livelihoods. On the other hand, participating in adult education decreases significantly the probability of water harvesting, crop diversification and livelihood diversification by 58.3, 36.4 and 80 percent respectively in highland mixed farming agro-ecosystem (Table 4). Similarly, participating in adult education decreases significantly the probability of water harvesting and changing livestock type/breeds by 64.8 and 41.5 percent respectively in lowland mixed farming ago-ecosystem (Table 5). The possible reason here might be that households may give less time to onfarm activities. In ago-pastoral agro-ecosystem, adult education increases significantly the probability of livelihood diversification by 95.7 percent (Table 6). The probable reason might be that education could likely enhance the households' ability to access information relevant to improve their livelihoods. On the other hand, adult education decreases significantly the probability of mobility by 45.5 percent (Table 6 ). The possible reason might be when household heads or members of a household attend adult education it affects the time to move from place to place in search of pasture and water especially during drought. Furthermore, adult education decreases significantly the probability of water harvesting, changing livestock type/breeds, livestock diversification, livelihood diversification, and mobility by $83,85.7,91.2,90.3$ and 82.1 percent respectively (Table 7 ). This might be due to the fact that adult educations are offered mostly in the regular program while most of the pastoralists are mobile.

\section{Access to Information}

Access to information increases significantly the probability of water harvesting, changing crop type/variety and changing planting date by $46.3,79.7$ and 99.9 percent respectively in highland mixed farming agro-ecosystem (Table 4). Moreover, access to information increases significantly the probability of water harvesting, changing crop type/variety, changing planting date, crop diversification, changing livestock type/breeds, livestock diversification, and migration by $70.6,44.9,83.8,86,41.3,46.7$ and 33.3 percent respectively in lowland mixed farming agro-ecosystem (Table 5). In line with this, key informants and focus group discussion participants argued that households with access to information are better in adapting to climate change impacts. A study conducted by Kansiime et al. (2014) asserted that access to weather information guides farmers/pastoralists in making adaptation decisions. In pastoral agro-ecosystem, access to information also increases significantly the probability of water harvesting, changing livestock type/breeds, livestock diversification, and livelihood diversification by 69, 76.3, 83.9, and 82.5 percent respectively (Table 7). This might be because of Dagu (the traditional information exchange mechanism of pastoralists) in which pastoralists exchange information to adapt to climate change especially during drought.

\section{Health Status}

Households with no members' illness increase significantly the probability of changing crop type/variety and soil and water conservation by 43.3 and 86.9 percent respectively in highland mixed farming agro-ecosystem (Table 4). Moreover, households with no members' illness increases significantly the probability of water harvesting, changing planting date and irrigation by $64.5,57.8$, and 70.6 percent respectively in lowland mixed farming agroecosystem (Table 5). Households with no members' illness also increase significantly the probability of water harvesting, changing livestock type/breeds, livestock diversification, livelihood diversification and mobility by 99.9, 85.7, 88.2, 95.7 and 94.6 percent respectively in agro-pastoral agro-ecosystem (Table 6). Furthermore, households with no members' illness increase significantly the probability of water harvesting, changing livestock type/breeds, livestock diversification, livelihood diversification, and mobility by 96.6, 96.2, 99.6, 99.6, and 98.3 percent respectively in pastoral agro-ecosystem (Table 7). The possible reason could be when the breadwinner or working age family members are healthy it enhances their ability to adapt to climate change. Similarly, as it was observed, and key informants and focus group discussion participants confirmed, healthiness of household heads and their members contribute positively for practicing adaptation strategies. A previous study conducted by WHO (2003) asserted that climate change affects human health which in turn affects productivity and food availability. 


\section{Social Networks}

Social networks (relations with relatives, friends and agricultural extension workers) increase significantly the probability of irrigation, livestock diversification and migration by 64.9, 36.4, and 52 percent respectively in highland mixed farming agro-ecosystem (Table 4). Moreover, social networks also increase significantly the probability of water harvesting, changing livestock type/breeds and livestock diversification by 66, 44.6 and 51.5 percent respectively in lowland mixed farming agro-ecosystem (Table 5). Similarly, in agro-pastoral agroecosystem, social networks increase significantly the probability of changing livestock type/breeds and mobility by 64.9 and 78.5 percent respectively (Table 6). In line with this, Balew et al. (2014) found that social network could improve the capacity of smallholder farmers to adopt/choose adaptation strategies. This shows that social networks are crucial to improve livelihoods. However, as it was observed and confirmed by key informants and participants in the focus group discussion, some households use the geo-membrane (whom they took from the agricultural office for water harvesting) for other purposes after they took with very low price. Previously conducted studies Deressa et al. (2008) and Balew et al. (2014) also asserted that social networks like having access to farmer-to-farmer extension increases the likelihood of using different crop varieties by 11.3 percent and planting trees by 12 percent. Furthermore, social networks increase significantly the probability of water harvesting, changing livestock type/breeds, livestock diversification, livelihood diversification, and mobility by $60.4,67.2,80.6,77.9$, and 72.1 percent respectively in pastoral agro-ecosystem (Table 7). For instance, as it was observed, Afar pastoralists have a social assistance like Hatot, which is mutual support to accomplish tasks like to harvest water in their locality.

\section{Institutional Membership}

Institutional membership (like a member of saving and credit association, and other kinds of cooperatives) increases significantly the probability of soil and water conservation, changing crop type/variety, crop diversification, changing livestock type/breeds and livelihood diversification by 14.3, 37.5, 23.5, 24.5 and 27.7 percent respectively in highland mixed farming agro-ecosystem (Table 4). In connection to this, Balew et al. (2014) asserted that farmers who are members of any farmers group found in the village have 11 percent higher probability of adapting to climate change using various method of adaptation. Moreover, in lowland mixed farming agroecosystem, institutional membership also increases significantly the probability of crop and livestock diversification by 64.9 and 41.2 percent respectively (Table 5). Likewise, Bazezew et al. (2013) found that people that share strong ideologies or beliefs and possess good experiences of cooperation are more likely to help each other during times of crises than people who are independent to each other, which in turn promotes positive livelihoods. This might be because of institutional membership like credit and saving institution or any association, which offers credit and labor; gives a chance of engaging in non-agricultural income generating activities and exchanging information about the better type of livestock and crops in resisting drought, productivity and better market prices. Furthermore, institutional membership increases significantly the probability of livestock diversification and livelihood diversification by 45.7 and 68.4 percent respectively in agro-pastoral agro-ecosystem (Table 6). Studies such as Deressa et al. (2008) and Balew et al. (2014) also asserted that farmers who are members of farmers groups are more likely to undertake adaptation to climate change.

\section{Land Ownership}

An increase in one timad (one-fourth hectare) land increases significantly the probability of water harvesting, changing crop type/variety, crop diversification, irrigation, and livestock diversification by 45.3, 55.5, 47, 97 and 79.1 percent respectively in highland mixed farming agro-ecosystem (Table 4). Meanwhile, key informants and focus group discussion participants argued that land ownership increases the adoption of various strategies. In relation to this, a study by Gbetibouo (2009) argued that adoption of an innovation will tend to take place earlier on larger farms than on smaller farms. Similarly, Balew et al. (2014) asserted that on average a hectare increase of a farmer's crop plot decreases the probability of adapting to climate change by 0.3 percent. Moreover, an increase in one timad land increases significantly the probability of changing crop type/variety, changing planting date, and changing livestock type/breeds by $19.5,13$, and 11.7 percent respectively in lowland mixed farming agroecosystem (Table 5). The possible reason might be when households have large farm size they are more likely to have better access to fodder especially from crop residue which in turn makes them to change their livestock based on their productivity and resisting ability to drought. Alternatively, an increase in one timad land decreases significantly the probability of migration by 47.4 percent in lowland mixed farming agro-ecosystem (Table 5). Furthermore, an increase in one timad land increases significantly the probability of changing livestock type/breeds, livestock diversification, livelihood diversification and mobility by 64.4, 40.1, 66.5 and 55.2 percent respectively in agro-pastoral agro-ecosystem (Table 6). This is because households, who have access to farmland, migrate to the areas where there are irrigation schemes and consequently they diversify their livelihood strategies through crop production. This is in line with a previously conducted study by Getachew et al. (2014) asserting that farm size plays pivotal role to adapt to changing climate. 


\section{Access to Irrigation Water}

Access to irrigation water increases significantly the probability of soil and water conservation, water harvesting, changing planting date, and irrigation by $89.2,38.7,56.4$ and 50.5 percent respectively in highland mixed farming agro-ecosystem (Table 4). Similarly, key informants and focus group discussion participants argued that households with water access for irrigation could harvest more and more water and increased the practice of irrigation. A previous study conducted by Ndambiri et al. (na), found that farmers with access to irrigation water were more likely to practice irrigation and other related options. Moreover, access to irrigation water also increases significantly the probability of soil and water conservation, water harvesting, crop diversification and irrigation by $54,31,46.6$ and 84.2 percent respectively in lowland mixed farming agro-ecosystem (Table 5). This is due to the fact that when households have access to water for irrigation they are more likely to harvest more water to benefit from irrigation and other related benefits. In line with, as it was observed, and key informants and focus group discussion participants confirmed, access to irrigation water has increased the practice of irrigation and crop diversification. In agro-pastoral agro-ecosystem, access to irrigation water decreases significantly the probability of livestock diversification and mobility by 46.2 and 42.1 percent respectively (Table 6). The probable reason might be when households have access to irrigation they would focus on crop production rather than livestock production and this in turn decreases the agro-pastoralists mobility. Moreover, as it was observed, this is due to the fact that when households have access to water, they refrain from moving in search of water and pasture. Furthermore, access to irrigation water increases significantly the probability of water harvesting by 76 percent in pastoral agro-ecosystem (Table 7). This is related to the fact that as households have access to irrigation water, they are more likely to harvest it.

Table 5: Marginal effects of multinomial logistic regression model for determinants of adaptation options in Lowland Mixed Farming agro-ecosystem

\begin{tabular}{|c|c|c|c|c|c|c|c|c|c|c|}
\hline$\overline{\text { Explanatory variables }}$ & $\begin{array}{l}\text { Soil \& water } \\
\text { conservation }\end{array}$ & $\begin{array}{c}\text { Water } \\
\text { harvesting }\end{array}$ & $\begin{array}{c}\text { Changing } \\
\text { crop } \\
\text { type/variety }\end{array}$ & $\begin{array}{c}\begin{array}{c}\text { Changing } \\
\text { planting } \\
\text { date }\end{array} \\
\end{array}$ & $\begin{array}{c}\text { Crop } \\
\text { diversification }\end{array}$ & Irrigation & $\begin{array}{c}\text { Changing } \\
\text { livestock } \\
\text { type/breeds }\end{array}$ & $\begin{array}{c}\text { Livestock } \\
\text { diversification }\end{array}$ & $\begin{array}{c}\text { Livelihood } \\
\text { diversification }\end{array}$ & $\begin{array}{c}\text { Migration/ } \\
\text { mobility }\end{array}$ \\
\hline $\begin{array}{l}\text { Gender } \\
\end{array}$ & 0.157 & 0.076 & $0.752^{* *}$ & -0.376 & -0.415 & 0.170 & $0.400^{*}$ & -0.332 & 0.044 & $0.622^{* * * *}$ \\
\hline Age & -0.007 & 0.027 & -0.008 & $-0.045^{* * *}$ & -0.013 & $-0.066^{*}$ & $-0.039^{* * *}$ & $-0.079^{* * * *}$ & 0.031 & -0.012 \\
\hline Marital status & $-0.924^{* * * *}$ & $-{ }^{-}$ & $-0.891^{* * *}$ & 0.157 & $-0.642^{* * * *}$ & $-0.703^{* * * *}$ & $0.442^{*}$ & -0.103 & -0.299 & $0.961 * * *$ \\
\hline Family planning & 0.021 & $-0.423 * *$ & -0.101 & $0.333^{*}$ & -0.053 & $0.549^{*}$ & -0.135 & 0.184 & $0.660^{\text {**** }}$ & -0.115 \\
\hline Household size & 0.103 & -0.111 & 0.232 & 0.042 & 0.264 & -0.127 & -0.141 & 0.068 & 0.142 & -0.124 \\
\hline Number of dependents & -0.145 & -0.220 & -0.197 & 0.141 & $-0.476^{* *}$ & -0.098 & $0.226^{*}$ & -0.030 & -0.088 & 0.212 \\
\hline Formal education & 0.549 & $\stackrel{-}{0.774^{* * *}}$ & 0.007 & -0.134 & $0.732^{* * *}$ & $-0.636^{* *}$ & $-0.411^{*}$ & 0.057 & 0.281 & $\stackrel{-}{0.837^{* * *}}$ \\
\hline Adult education & $0.656^{* *}$ & $0.648^{* * *}$ & 0.163 & -0.384 & 0.179 & -0.362 & $-0.415^{* * *}$ & -0.347 & 0.110 & -0.299 \\
\hline Access to information & -0.224 & $0.706^{* * * *}$ & $0.449^{* *}$ & $0.838^{* * *}$ & $0.860^{* * *}$ & -0.012 & $0.413^{* * *}$ & $0.467 * *$ & 0.247 & $0.333^{*}$ \\
\hline Farming experience & -0.022 & $-0.073^{* * *}$ & -0.042 & 0.035 & -0.045 & 0.055 & $0.040^{*}$ & $0.064 * *$ & -0.023 & 0.012 \\
\hline Health status & -0.209 & $0.645^{* * *}$ & 0.017 & $0.578^{* *}$ & -0.286 & $0.706^{* * * *}$ & 0.330 & 0.185 & -0.064 & 0.329 \\
\hline Social networks & -0.209 & $0.660^{* * *}$ & 0.117 & 0.367 & 0.328 & -0.205 & $0.446^{* * *}$ & $0.515^{* * * *}$ & -0.198 & -0.500 \\
\hline Institutional membership & 0.030 & 0.031 & -0.436 & 0.097 & $0.649^{* * *}$ & -0.263 & 0.150 & $0.412^{* * *}$ & -0.251 & -0.381 \\
\hline Land ownership***** & 0.039 & -0.094 & $0.195 * *$ & $0.130^{*}$ & 0.037 & 0.067 & $0.117^{* * *}$ & 0.084 & 0.053 & $-0.474^{* *}$ \\
\hline Irrigation water access & $0.540^{* * * *}$ & $0.310^{* * * *}$ & 0.125 & 0.018 & $0.466 * * *$ & $0.842^{* * * *}$ & -0.002 & -0.134 & 0.138 & -0.069 \\
\hline Road distance & -0.110 & $\widetilde{0.671^{* * *}}$ & -0.002 & -0.085 & -0.976 & $-0.491^{* * *}$ & -0.075 & $-0.629^{* * *}$ & $-0.992^{* * *}$ & $-0.818^{*}$ \\
\hline Market distance & 0.218 & $-0.442^{*}$ & 0.146 & 0.103 & 0.068 & $-0.710^{* *}$ & -0.088 & $-0.394^{*}$ & -0.131 & -0.098 \\
\hline Clean water access & $0.289^{*}$ & $0.306^{*}$ & 0.132 & -0.053 & 0.150 & $0.360^{*}$ & 0.022 & 0.159 & -0.048 & 0.053 \\
\hline Mobile phone & 0.063 & -0.345 & $0.461^{*}$ & $0.401^{* *}$ & -0.130 & -0.082 & -0.210 & $0.752^{* * *}$ & 0.082 & 0.034 \\
\hline Saving & 0.032 & $0.812^{* * * *}$ & $0.511^{* *}$ & -0.025 & -0.095 & -0.105 & -0.146 & 0.077 & $0.444^{* * * *}$ & 0.082 \\
\hline Credit taking & -0.115 & -0.313 & 0.188 & -0.101 & $0.528 * *$ & -0.221 & 0.071 & $0.476^{* * * *}$ & 0.009 & -0.182 \\
\hline Livestock ownership***** & $0.205^{* * * *}$ & $0.201 * * *$ & 0.066 & 0.005 & $0.125^{*}$ & 0.052 & -0.062 & 0.003 & $0.260^{* * * *}$ & -0.014 \\
\hline Non-agricultural income & 0.040 & $\stackrel{-}{0.592^{* * *}}$ & $-0.537^{* * *}$ & $0.340^{*}$ & 0.280 & 0.020 & -0.317 & 0.154 & $-0.252^{* *}$ & $0.597 * * *$ \\
\hline Agricultural extension & -0.013 & -0.038 & -0.264 & -0.249 & $0.822^{* * *}$ & $0.906^{* * * *}$ & 0.023 & $0.548^{* * * *}$ & -0.142 & 0.004 \\
\hline Access to credit institution & -0.193 & 0.355 & 0.073 & $0.363^{*}$ & $0.483^{* *}$ & -0.087 & $0.354^{* *}$ & $0.652^{* * *}$ & $0.333^{* *}$ & $0.573 * * *$ \\
\hline Market access & -0.230 & $0.739^{* * *}$ & -0.072 & 0.187 & $0.409^{* * * *}$ & $0.583^{* * * *}$ & -0.100 & $0.393 *$ & $0.744^{* * * *}$ & -0.060 \\
\hline School distance & 0.427 & 0.285 & 0.292 & 0.327 & 0.127 & -0.627 & 0.006 & $0.508^{*}$ & -0.013 & 0.143 \\
\hline Health post distance & -0.342 & -0.099 & -0.405 & -0.163 & -0.471 & 0.370 & -0.013 & -0.195 & -0.038 & -0.262 \\
\hline Perception of temp. increase & 0.069 & $0.392^{* *}$ & $0.218^{* *}$ & 0.265 & 0.238 & $0.580^{* * *}$ & 0.068 & -0.136 & -0.034 & -0.065 \\
\hline Perception of Rainfall decrease & $0.335^{* *}$ & -0.369 & -0.086 & $0.470^{* * *}$ & -0.250 & -0.351 & $0.538^{* * * *}$ & $0.416^{* *}$ & -0.067 & -0.001 \\
\hline Drought occurrence frequency & $0.598^{* * *}$ & $0.957^{* * *}$ & $0.674^{* * * *}$ & $0.440^{* * *}$ & $0.632^{* * *}$ & $0.664^{* * * *}$ & $0.251^{*}$ & $0.646^{* * *}$ & 0.179 & 0.049 \\
\hline Crop failure & -0.232 & -0.179 & -0.098 & 0.168 & 0.156 & -0.178 & 0.139 & 0.031 & $-0.380^{* * * *}$ & -0.087 \\
\hline Livestock death & -0.112 & -0.004 & $-0.540^{* * *}$ & 0.084 & -0.224 & 0.177 & -0.238 & $-0.468^{* * * *}$ & 0.071 & 0.113 \\
\hline Water scarcity & -0.185 & $0.568^{* * *}$ & -0.216 & -0.064 & $0.383^{* * *}$ & $0.507^{* *}$ & -0.095 & -0.055 & $0.386^{* * * *}$ & -0.105 \\
\hline Food shortage & 0.212 & 0.330 & 0.073 & -0.232 & 0.256 & $0.571^{* *}$ & 0.046 & -0.019 & 0.109 & $0.509^{* *}$ \\
\hline Conflict occurrence & -0.175 & -0.153 & -0.022 & -0.103 & 0.120 & $-0.612^{* * * *}$ & $-0.198^{*}$ & $-0.236^{*}$ & 0.089 & -0.036 \\
\hline \multicolumn{11}{|l|}{$\begin{array}{l}\text { Diagnostics } \\
\text { Base category }\end{array}$} \\
\hline Base category & & & & $\begin{array}{c}\text { No } \\
\text { adaptation }\end{array}$ & & & & & & \\
\hline Number of observations & & & & 180 & & & & & & \\
\hline LR chi - square & 153.4 & 156.8 & 148.7 & 133.8 & 153.1 & 171.9 & 73.7 & 130.7 & 126.2 & 173.8 \\
\hline Log likelihood & -47.2 & -45.8 & -49.5 & -57.7 & -48.0 & -38.6 & -87.7 & -59.1 & -60.3 & -37.8 \\
\hline Pseudo R - square & 0.619 & 0.631 & 0.60 & 0.537 & 0.615 & 0.69 & 0.296 & 0.525 & 0.511 & 0.697 \\
\hline
\end{tabular}

Source: Field Survey, 2014

Note: $* * *$ significant at $1 \%, * *$ significant at $5 \%, *$ significant at $10 \%$

$* * * * 4$ timads are equal to 1 hectare

$* * * * *$ Tropical Livestock Unit (TLU) conversion factors: camel $=1$, cattle $=0.7$, horse $=0.8$, mule $=0.7$, donkey $=0.5$, sheep/goat $=0.1$, chicken $=0.01$ (Source: FAO, 1987).

\section{Road Distance}

An hour increase in traveling time to get the nearest all weather road decreases significantly the probability of irrigation and changing livestock type/breeds by 34 and 98.9 percent in highland mixed farming agro-ecosystem (Table 4). Similarly, as it was observed and discussed with key informants and focus group discussion participants the remoteness of getting the nearest all weather road decreases the adoption of adaptation strategies like irrigation. 
A study by Worku (2011) also asserted that easy access to roads enhance adaptive capacity of households. Moreover, a study conducted by Piya et al. (2012) indicated that an increase in a walking distance to the nearest road negatively affects the adaptive capacity of households to climate change impacts. Moreover, an hour increase in traveling time to get the nearest all weather road decreases significantly the probability of water harvesting, irrigation, livestock diversification, livelihood diversification and mobility by $67.1,49.1,92.9,99.2$ and 81.2 percent respectively in lowland mixed farming agro-ecosystem (Table 5). For instance, key informants and focus group discussion participants argued, when households have no easy road and market access, they hardly practice irrigation due to lack of market to sell the products. An hour increase in traveling time to get the nearest all weather road decrease significantly the probability of migration by 19.8 percent in agro-pastoral agro-ecosystem (Table 6). The possible reason might be when households have road access they migrate to the nearest urban areas and vice versa. Key informants and focus group discussion participants have pointed out that households would not migrate to urban areas if they would not have access to road in their locality. Similarly, an hour increase in traveling time to get the nearest all weather road decreases significantly the probability of livestock and livelihood diversification by 74.4 and 56.3 percent respectively in pastoral agro-ecosystem (Table 7). The possible reason might be that households became far from the market centers that minimizes the opportunity of diversifying their livelihood strategies with non/off-farm activities.

\section{Market Distance}

An hour increase in traveling time to get the nearest market place decreases significantly the probability of livelihood diversification by 47.7 percent in highland mixed farming agro-ecosystem (Table 4). This might be when there is market access; households could diversify their livelihood strategies. Similarly, Balew et al. (2014) confirmed that farmers who had to walk for an additional 1 minute to arrive at the nearest input and output market have a 10 percent lower probability to adapt to climate change. An hour increase in traveling time to get the nearest market place decreases significantly the probability of water harvesting, irrigation and livestock diversification by 44.2, 71 and 39.4 percent respectively in lowland mixed farming agro-ecosystem (Table 5). This is because remoteness of the market centers creates difficulty for households to engage in causal works. In relation to this, Balew et al. (2014) found that farmers who are located near to the market had higher probability to use different adaptation options including water harvesting. An hour increase in traveling time to get the nearest market place decreases significantly the probability of livelihood diversification by 51.3 percent in agro-pastoral agroecosystem (Table 6). A study by Gebrehiwot and Fekadu (2012) also asserted that easy access to market reduces transaction costs, and enhance non-farm employments.

\section{Clean Water Access}

Clean water access increases significantly the probability of changing livestock type/breeds and livelihood diversification by 40.2 and 32.9 percent respectively in highland mixed farming agro-ecosystem (Table 4). Similarly, clean water access increases significantly the probability of soil and water conservation, water harvesting and irrigation by 28.9, 30.6 and 36 percent respectively in lowland mixed farming agro-ecosystem (Table 5). In line with, key informants and focus group discussion participants argued, households who have access to clean water become healthy and can shift their labor and time that would be lost in fetching water to different adaptation strategies such as soil and water conservation, irrigation, crop diversification, and engaging in some income generating activities. Previous studies asserted that as people become healthier with the provision of clean water and sanitation, they would become more productive (UNDP, 2006). Clean water access increases significantly the probability of livelihood diversification, changing livestock type/breeds and mobility by 99.2 , 42.6 and 40.2 percent respectively in agro-pastoral agro-ecosystem (Table 6). The probable reason for the first adaptation strategy is that when households have clean water access, they would save the time lost for fetching and purifying the water, which in turn used for diversifying their livelihood strategies. Moreover, clean water access increases significantly the probability of water harvesting, changing livestock type/breeds, livestock diversification, livelihood diversification, and mobility by 84.7, 82.4, 93.7, 94.1, and 73.9 percent respectively in pastoral agro-ecosystem (Table 7). This might be when households have access to clean water; they would be healthy and productive.

\section{Mobile Phone Possession}

Mobile phone possession increases significantly the probability of water harvesting and livelihood diversification by 43.7 and 43.4 percent respectively in highland mixed farming agro-ecosystem (Table 4). Mobile phone possession also increases significantly the probability of changing crop type/variety, changing planting date and livestock diversification by $46.1,40.1$ and 75.2 percent respectively in lowland mixed farming agro-ecosystem (Table 5). Similarly, key informants have indicated that households who have mobile phone have access to information and in turn, they are better in practicing adaptation strategies. Moreover, mobile phone possession increases significantly the probability of livestock diversification by 61 percent in agro-pastoral agro-ecosystem 
(Table 6). This might be when households have mobile phone they do have better market information to diversify livestock. Similarly, key informants and focus group discussion participants argued that households who get information about the drought resistant livestock are more likely to shift from highly drought-affected livestock to drought resistance livestock like shoats and camels. A study asserted that access to information from different sources had a positive influence on the probability of employing different adaptation options (Hadgu et al., 2015).

\section{Saving}

Households who have saving increases significantly the probability of water harvesting, changing crop type/variety and changing livestock type/breeds and livelihood diversification by $46.8,41.2,77.1$ and 47.5 percent respectively percent respectively in highland mixed farming agro-ecosystem (Table 4). Saving also increases significantly the probability of water harvesting,changing crop type/variety and livelihood diversification by 81.2,51.1 and 44.4 percent respectively in lowland mixed farming agro-ecosystem (Table 5). The probable reason might be when households have saving they are more likely to purchase different agricultural inputs to change the crop type or variety. This might be related to the fact that as households save more, they might start a better business in the nearby urban areas to diversify their livelihoods with crop production, livestock production and small off-farm and non-farm activities. In line with this, Gbetibouo (2009) and Shiferaw (2014) indicated that lack of financial resources is one of the main constraints to climate change adaptation. Saving decreases significantly the probability of changing livestock type/breeds, livestock diversification and livelihood diversification by 54.5, 39.9 and 39.4 percent respectively in agro-pastoral agro-ecosystem (Table 6). Similarly, saving decreases significantly the probability of changing livestock type/breeds, livestock diversification and livelihood diversification by $54.5,39.9$ and 39.4 percent respectively in pastoral agro-ecosystem (Table 7). The possible reason might be households may save their money in banks rather than purchasing livestock, which was the previous way of saving their money.

\section{Credit Taking}

Credit taking increases significantly the probability of water harvesting, livestock diversification, livelihood diversification and migration by $49,49.4,45.7$ and 31.4 percent respectively in highland mixed farming agroecosystem (Table 4). This is because as households have taken credit, they might start a better business in their nearby urban area to diversify their livelihoods with crop production, livestock production and off-farm and nonfarm activities. Credit taking increases significantly the probability of crop and livestock diversification by 52.8 and 47.6 percent respectively in lowland mixed farming agro-ecosystem (Table 5). Likewise, access to affordable credit increases financial resources of farmers and pastoralists and their ability to meet transaction costs associated with adaptation strategies (Getachew et al., 2014; Hassan and Nhemachena, 2008). Bazezew et al. (2013) also found that as credit availability increases by one unit, annual income of households' increases by a factor of 0.242 , which in turn increases the ability of households to adapt to climate change.

\section{Livestock Ownership}

An increase in one TLU increases significantly the probability of changing livestock type/breeds, and livestock diversification by 69.9 and 64 percent respectively in highland mixed farming agro-ecosystem (Table 4). Similarly, an increase in one TLU increases significantly the probability of soil and water conservation, water harvesting, crop diversification and livelihood diversification by 20.5, 20.1,12.5 and 26 percent respectively in lowland mixed farming agro-ecosystem (Table 5). Bazezew et al. (2013) also found that a unit increase in livestock ownership (in TLU) increases annual household income by a factor of 0.33 that lifts households' capacity to respond to climate change impacts. However, a study conducted by Gecho et al. (2014) asserted that households having larger size of livestock are less likely to diversify the livelihood strategies into non-farm and/or off-arm activities compared to those who own small number of TLUs. An increase of one TLU increases significantly the probability of mobility by 16.3 percent in agro-pastoral agro-ecosystem (Table 6). Similarly, an increase in one TLU increases significantly the probability of livestock diversification and livelihood diversification by 11.5 and 11.9 percent respectively in pastoral agro-ecosystem (Table 7). Likewise, Balew et al. (2014) indicated that on average a 1unit increase in livestock holding increases the probability of adapting to climate change by 1 percent.

\section{Non-agricultural Income}

Having non-agricultural income source increases significantly the probability of changing livestock type/breeds by 75.2 percent in highland mixed farming agro-ecosystem (Table 4). Having non-agricultural income source also increases significantly the probability of changing planting date by 34 percent in lowland mixed farming agroecosystem (Table 5). Moreover, having non-agricultural income source increases significantly the probability of water harvesting, changing livestock type/breeds, livestock diversification, livelihood diversification, and mobility by $94.2,96.1,99.4,99.2$ and 95.7 percent respectively in pastoral agro-ecosystem (Table 7). For instance, this might be related to the fact that when households have non-agricultural income source they do have better capacity of purchasing various agricultural inputs to change planting date many times if they face crop failure. A previously 
conducted study also indicated that households with non-agricultural income increase the likelihood of improving crop variety and crop diversification (Tazeze et al., 2012). On the contrary, having non-agricultural income source decreases significantly the probability of livestock and livelihood diversification by 55.9 and 56.4 percent respectively (Table 4). Similarly, having non-agricultural income decreases significantly the probability of water harvesting, changing crop type/variety, livelihood diversification and migration by 59.2, 53.7, 25.2 and 59.7 percent respectively (Table 5). Moreover, having non-agricultural income source decreases significantly the probability of changing livestock type/breeds and livestock diversification by 64.6 and 65.2 percent respectively in agro-pastoral agro-ecosystem (Table 6). This is because that when households have non-agricultural income source they are most likely to give less time to on-farm activities like livestock and crop production. A study by Shiferaw (2014) found that as the farmers' income from non-farm activities increased they devote less and less time for farming activities.

\section{Agricultural Extension}

Agricultural extension services increase significantly the probability of changing crop type/variety, changing planting date, irrigation, livelihood diversification, and migration by $63.1,98.2,58.2,63.6$ and 31.9 percent respectively in highland mixed farming agro-ecosystem (Table 4). Agricultural extension services also increases significantly the probability of crop diversification, irrigation and livestock diversification by $82.2,90.6$ and 54.8 percent respectively in lowland mixed farming agro-ecosystem (Table 5). Moreover, agricultural extension services increases significantly the probability of livestock diversification by 49.4 percent in agro-pastoral agroecosystem (Table 6). Furthermore, agricultural extension services increases significantly the probability of water harvesting, changing livestock type/breeds, livestock diversification, livelihood diversification, and mobility by $64.3,80.4,90.3,87$ and 75 percent respectively in pastoral agro-ecosystem (Table 7). This is along the lines of the previous studies, Getachew et al. (2014) and Tadesse et al. (2008) indicating that access to crop and livestock extension services significantly increases the likelihood of adaptation. Atinkut and Mebrat (2016) also found that farmers' who have access to extension services are more likely to be aware of climatic conditions and adopt adaptation measures. On the other hand, agricultural extension services decrease significantly the probability of livelihood diversification by 64.2 percent (Table 6). This might be because of the credibility of the services in which most households are not accepting the advice of development agents and the way the development agents are tailoring knowledge and skills to the households. For instance, a key informant has argued that households took chickpea improved variety, however, they yield nothing. A previously conducted study by Kansiime et al. (2014) asserted that extension services not tailored to the existing farmer challenges are valueless. Moreover, Kristin (2008) pointed out that a combination of lack of relevant technology, lack of incentives for extension agents, and weak linkages between extension, research, and farmers affects the role of agricultural extension services.

Table 6: Marginal effects of multinomial logistic regression model for determinants of adaptation options in Agropastoral agro-ecosystem

\begin{tabular}{|c|c|c|c|c|c|}
\hline $\begin{array}{l}\text { Explanatory } \\
\text { variables }\end{array}$ & $\begin{array}{c}\text { Water } \\
\text { harvesting }\end{array}$ & $\begin{array}{c}\text { Changing } \\
\text { livestock } \\
\text { type/breeds }\end{array}$ & $\begin{array}{c}\text { Livestock } \\
\text { diversification }\end{array}$ & $\begin{array}{c}\text { Livelihood } \\
\text { diversification }\end{array}$ & $\begin{array}{l}\text { Migration/ } \\
\text { mobility }\end{array}$ \\
\hline Gender & -0.425 & 0.325 & $0.718 * *$ & $0.843 * *$ & $-0.995 * * *$ \\
\hline Age & 0.239 & $-0.323 * *$ & -0.183 & $0.589 *$ & $0.309 * *$ \\
\hline Marital status & 0.293 & 0.337 & $-0.662 * *$ & $0.881 * * *$ & $0.627 * * *$ \\
\hline Family planning & 0.514 & -0.034 & 0.219 & 0.039 & -0.140 \\
\hline Household size & 0.178 & -0.435 & -0.351 & 0.085 & 0.203 \\
\hline $\begin{array}{l}\text { Number } \quad \text { of } \\
\text { dependents }\end{array}$ & -0.826 & $0.425 * *$ & $0.951 * *$ & -0.464 & $-0.583 *$ \\
\hline Formal education & 0.790 & $-0.843 * * *$ & $-0.782 * * *$ & $0.738^{*}$ & $0.936 * * *$ \\
\hline Adult education & 0.736 & -0.006 & -0.100 & $0.957 * * *$ & $-0.455^{* *}$ \\
\hline $\begin{array}{ll}\text { Access } & \text { to } \\
\text { information } & \end{array}$ & 0.958 & 0.470 & 0.167 & -0.427 & 0.089 \\
\hline Farming experience & -0.283 & $0.360 * *$ & $0.277^{*}$ & $-0.646^{*}$ & $-0.333^{* *}$ \\
\hline Health status & $0.999 * * *$ & $0.857 * * *$ & $0.882 * * *$ & $0.957 * * *$ & $0.946 * * *$ \\
\hline Social networks & 0.507 & $0.649 * * *$ & -0.035 & -0.499 & $0.785 * * *$ \\
\hline $\begin{array}{l}\text { Institutional } \\
\text { membership }\end{array}$ & 0.561 & -0.355 & $0.457 * *$ & $0.684 * * *$ & -0.125 \\
\hline $\begin{array}{l}\text { Land } \\
\text { ownership**** }\end{array}$ & 0.328 & $0.644 * *$ & $0.401 *$ & $0.665^{*}$ & $0.552 * *$ \\
\hline $\begin{array}{l}\text { Irrigation water } \\
\text { access }\end{array}$ & 0.030 & 0.317 & $-0.462 *$ & -0.301 & $-0.421 * *$ \\
\hline
\end{tabular}




\begin{tabular}{|c|c|c|c|c|c|}
\hline $\begin{array}{l}\text { Explanatory } \\
\text { variables }\end{array}$ & $\begin{array}{c}\text { Water } \\
\text { harvesting }\end{array}$ & $\begin{array}{c}\text { Changing } \\
\text { livestock } \\
\text { type/breeds }\end{array}$ & $\begin{array}{c}\text { Livestock } \\
\text { diversification }\end{array}$ & $\begin{array}{c}\text { Livelihood } \\
\text { diversification }\end{array}$ & $\begin{array}{l}\text { Migration/ } \\
\text { mobility }\end{array}$ \\
\hline Road distance & -0.197 & 0.774 & 0.594 & -0.425 & $-0.198 * *$ \\
\hline Market distance & -0.040 & 0.447 & 0.574 & $0.513 * * *$ & -0.299 \\
\hline Clean water access & 0.524 & $0.426^{* *}$ & -0.132 & $0.992 * * *$ & $0.402 *$ \\
\hline Mobile phone & -0.393 & -0.235 & $0.610 * *$ & -0.519 & -0.372 \\
\hline Saving & 0.169 & $-0.185 * *$ & $-0.124 *$ & $-0.202 * * *$ & 0.174 \\
\hline \multicolumn{6}{|l|}{ Credit taking } \\
\hline $\begin{array}{l}\text { Livestock } \\
\text { ownership***** }\end{array}$ & -0.053 & -0.043 & -0.038 & -0.137 & $0.163 *$ \\
\hline $\begin{array}{l}\text { Non-agricultural } \\
\text { income }\end{array}$ & 0.447 & $-0.646 * * *$ & $-0.652 * * *$ & 0.624 & 0.335 \\
\hline $\begin{array}{l}\text { Agricultural } \\
\text { extension }\end{array}$ & 0.292 & 0.117 & $0.494 *$ & $-0.642 * *$ & -0.053 \\
\hline \multicolumn{6}{|l|}{$\begin{array}{l}\text { Access to credit } \\
\text { institution }\end{array}$} \\
\hline Market access & 0.071 & 0.143 & $0.636 * *$ & $0.792 * * *$ & $0.427 *$ \\
\hline School distance & 0.492 & $-0.863 * *$ & -0.011 & -1.412 & 0.368 \\
\hline Health post distance & -0.972 & $-0.627 * *$ & -0.034 & $-0.223 * *$ & 0.201 \\
\hline $\begin{array}{l}\text { Perception of temp. } \\
\text { increase }\end{array}$ & 0.808 & $0.845^{* * *}$ & $0.900 * * *$ & $0.808 * *$ & $0.940 * * *$ \\
\hline $\begin{array}{l}\text { Perception of } \\
\text { Rainfall decrease }\end{array}$ & 0.944 & $0.713^{*}$ & 0.653 & -0.534 & $0.985 * * *$ \\
\hline $\begin{array}{l}\text { Drought occurrence } \\
\text { frequency }\end{array}$ & -0.992 & $0.692 * *$ & $0.723 * * *$ & -0.668 & $0.922 * * *$ \\
\hline Crop failure & $0.995 * * *$ & $0.998 * * *$ & $0.988 * * *$ & -0.000 & $0.999 * * *$ \\
\hline Livestock death & 0.215 & $0.598 * * *$ & 0.273 & 0.169 & -0.057 \\
\hline Water scarcity & -0.282 & -0.092 & -0.005 & $0.586^{* *}$ & 0.098 \\
\hline Food shortage & -0.680 & -0.499 & 0.726 & $0.806^{*}$ & $0.862 * * *$ \\
\hline Conflict occurrence & 0.522 & $-0.876 * * *$ & $-0.599 * *$ & 0.210 & $-0.553 * * *$ \\
\hline \multicolumn{6}{|l|}{ Diagnostics } \\
\hline Base category & & No adaptation & & & \\
\hline $\begin{array}{l}\text { Number } \\
\text { observations }\end{array}$ & & 48 & & & \\
\hline LR chi - square & 78.80 & 67.4 & 58.7 & 77.6 & 56.7 \\
\hline Log likelihood & -60.4 & -66.1 & -69.8 & -60.9 & -68.3 \\
\hline Pseudo R - square & 0.395 & 0.338 & 0.296 & 0.389 & 0.293 \\
\hline
\end{tabular}

Source: Field Survey, 2014

Note: $* * *$ significant at $1 \%, * *$ significant at $5 \%, *$ significant at $10 \%$

$* * * * 4$ timads are equal to 1 hectare

$* * * * *$ Tropical Livestock Unit (TLU) conversion factors: camel $=1$, cattle $=0.7$, horse $=0.8$, mule $=0.7$, donkey

$=0.5$, sheep/goat $=0.1$, chicken $=0.01($ Source: FAO, 1987) .

\section{Credit Access}

Credit access increases significantly the probability of irrigation, changing livestock type/breeds, livestock diversification and livelihood diversification by 44.1, 60.6, 71.8 and 70.4 percent respectively in highland mixed farming agro-ecosystem (Table 4). As it was observed and confirmed by key informants and participants from the focus group discussion, households who have credit access are more likely to practice irrigation and livelihood diversification. As Hadgu et al. (2015) also found increased access to credit is likely to increase the probability of the household to practice irrigation by 22.7 percent. Credit service also increases significantly the probability of changing planting date, crop diversification, changing livestock type/breeds, livestock diversification, livelihood diversification and migration by $36.3,48.3,35.4,65.2,33.3$ and 57.3 percent respectively in lowland mixed farming agro-ecosystem (Table 5). This might be when households have access to credit it increases the chance of engagement in off-farm and non-farm activities in addition to on-farm activities or adaptation options. In relation to this, a study conducted by Tessema et al. (2013) indicated that farmers accessing credit are likely to engage in different farm investment activities that improve their adaptive capacity and thereby delaying other adaptation measures. 


\section{Market Access}

Market access increases significantly the probability of soil and water conservation, water harvesting changing crop type/variety, crop diversification, irrigation, livestock diversification, livelihood diversification and migration by $93.7,65.6,67.8,27.5,94.2,79.2,61.5$ and 54.7 percent respectively in highland mixed farming agro-ecosystem (Table 4). Similarly, market access is an important determinant to adaptation to climate change (Hassan and Nhemachena, 2008). Market access also increases significantly the probability of water harvesting, crop diversification, irrigation, livestock diversification and livelihood diversification by 73.9, 40.9, 58.3, 39.3 and 74.4 percent respectively in lowland mixed farming agro-ecosystem (Table 5). The possible reason might be when the households have better market access; they are more likely to diversify their livestock to benefit from different livestock markets. Similarly, as it was observed and confirmed by key informants, market access has made households more likely to practice irrigation and diversify livelihood strategies. Moreover, market access increases significantly the probability of livestock diversification, livelihood diversification and mobility by 63.6, 79.2 and 42.7 percent respectively in agro-pastoral agro-ecosystem (Table 6). In relation to this, as Tesfay (2014) found, when farmers' are far away from the market center, they would not obtain better information, share experience and unable to buy new adaption technologies and other inputs. Furthermore, market access increases significantly the probability of changing livestock type/breeds, livestock diversification, livelihood diversification and mobility by $94.1,97.9,95.3$ and 92.5 percent respectively in pastoral agro-ecosystem (Table 7). As it is observed and supported by key informants and focus group discussion participants, when there is better market access there is high tendency of households to improve their productivity. Similarly, a study confirmed that better access to markets enables farmers to buy new soil and water conservation technologies and other important inputs (Tazeze et al., 2012).

\section{Primary School Distance}

Primary school distance increases significantly the probability of livestock diversification by 50.8 percent in lowland mixed farming agro-ecosystem (Table 5). This might be when primary schools are far to the households, they would not send their children to school that in turn helps the households to get the labor of their children. However, primary school distance decreases significantly the probability of changing livestock type/breeds by 86.3 percent in agro-pastoral agro-ecosystem (Table 6). This might be when there is better school access there is high tendency of households to send their children to school that in turn creates labor shortage. A study done by Addis and Assefa (2013) asserted that households send their children to school as far as they would not face labor shortage, however; they dropout when their labor is demanded by the household.

\section{Health Post Distance}

Health post distance decreases significantly the probability of changing livestock type/breeds by 46.5 percent in highland mixed farming agro-ecosystem (Table 4). This might be when there is better health service/access there is high tendency of households to improve their productivity, as they would be healthy. Similarly, health post distance decreases significantly the probability of changing livestock type/breeds and livelihood diversification by 62.7 and 22.3 percent respectively in agro-pastoral agro-ecosystem (Table 6). Furthermore, health post distance decreases significantly the probability of water harvesting, changing livestock type/breeds, livestock diversification, and livelihood diversification by $65.1,77.7,9.6$, and 10.1 percent respectively in pastoral agroecosystem (Table 7). A study asserted that pastoral and agro-pastoral communities' poor access to health services, and availability of few resources at their disposal, make them very vulnerable especially when hazards occur (Riche et al., 2009). On the other hand, health post distance increases significantly the probability of mobility by 74.8 percent in pastoral agro-ecosystem (Table 7). The possible reason for mobility might be as there are no social services like health institutions in their vicinity; households would not lead a settled life.

\section{Perception of Temperature Increase}

Households who perceive temperature increase for the last 20 to 30 years increase significantly the probability of soil and water conservation, water harvesting, changing crop type/variety and livelihood diversification by 99.5 , 38.3, 38.2 and 53.6 percent respectively in highland mixed farming agro-ecosystem (Table 4). Households who perceive temperature increase for the last 20 to 30 years also increase significantly the probability of water harvesting, changing crop type/variety and irrigation by 39.2, 21.8 and 58 percent respectively in lowland mixed farming agro-ecosystem (Table 5). For instance, as it was observed and confirmed by key informants, temperature increase perception makes households more likely to conserve soil and water on their farm plots. A study by Shiferaw (2014) confirmed this stating that households who perceive temperature change are adopting different adaptation options. More specifically, a study conducted by Atinkut and Mebrat (2016) found that farmers' who perceived a change in temperature are more likely to adapt to climate variability by 16 and 14 times greater compared to those who do not perceived a rise in temperature. Gbetibouo (2009) also found the same result in that 
farmers' who are aware of changes in climatic conditions have higher chances of taking adaptive measures in response to the observed changes. Moreover, perceiving temperature increase for the last 20 to 30 years increases significantly the probability of changing livestock type/breeds, livestock diversification, livelihood diversification and mobility by $84.5,90,80.8$ and 94 percent respectively in agro-pastoral agro-ecosystem (Table 6). A study conducted by Atinkut and Mebrat (2016) also asserted that perception of households' to the increasing temperature positively and significantly correlated with the choice of crop-diversification and soil and water conservation. Moreover, households who perceive temperature increase for the last 20 to 30 years increase significantly the probability of water harvesting, changing livestock type/breeds, livestock diversification, livelihood diversification, and mobility by $91.9,94.2,98,97.3$ and 94.3 percent respectively in pastoral agro-ecosystem (Table 7). Similarly, key informants and participants in the focus group discussion have asserted that when households perceive temperature increase, they are most likely to diversify their livestock with browsers and grazers as they suspect drought and not be a complete loser.

\section{Perception of Rainfall Decrease}

Households who perceive rainfall decrease for the last 20 to 30 years increase significantly the probability of changing crop type/variety, changing planting date, crop diversification, changing livestock type/breeds, livestock diversification and mobility by 50.9, 91.5, 72.8, 75.3, 63.2 and 37.9 percent respectively in highland mixed farming agro-ecosystem (Table 4). Similarly, households who perceive rainfall decrease for the last 20 to 30 years increases significantly the probability of soil and water conservation, changing planting date, changing livestock type/breeds and livestock diversification by $47,53.8,41.6$ and 33.5 percent respectively in lowland mixed farming agroecosystem (Table 5). Similarly, key informants and focus group discussion participants have argued that increasing rainfall relaxes the households in employing different adaptation strategies. Households who perceive rainfall decrease for the last 20 to 30 years also increase significantly the probability of changing livestock type/breeds and mobility by 71.3 and 98.5 percent respectively in agro-pastoral agro-ecosystem (Table 6 ). The possible reason might be when households perceive rainfall decrease they forecast there would be drought and they should diversify their livestock to minimize risks of livestock death due to drought. Households who perceive rainfall increase for the last 20 to 30 years increase significantly the probability of water harvesting, changing livestock type/breeds, livestock diversification, livelihood diversification, and mobility by 98.7, 99.1, 99.9, 99.8 and 99 percent respectively in pastoral agro-ecosystem (Table 7). In line with, a study by Gbetibouo (2009) has asserted that households experiencing the effects of decreased precipitation are more likely to build water-harvesting schemes.

\section{Drought Occurrence Frequency}

Households', who face drought yearly, increase significantly the probability of livestock diversification by 93.2 percent in highland mixed farming agro-ecosystem (Table 4). Similarly, households who face drought yearly increases significantly the probability of soil and water conservation, water harvesting, changing crop type/variety, changing planting date, crop diversification, irrigation, changing livestock type/breeds and livestock diversification by $59.9,95.7,67.4,44,63.2,66.4,25.1$ and 64.6 percent respectively in lowland mixed farming agro-ecosystem (Table 5). In relation to this, a study conducted by Deressa et al. (2008) indicated that increased drought frequency significantly increases the likelihood of using different adaptation measures such as soil conservation, changing crop varieties, changing planting dates, and irrigating. Moreover, households who face drought yearly increase significantly the probability of changing livestock type/breeds, livestock diversification and mobility by 69.2 and 72.3 and 92.2 percent respectively in agro-pastoral agro-ecosystem (Table 6). As it was discussed previously, when households face drought yearly, they are more likely to diversify their livestock with browsers and grazers. Furthermore, households who face drought yearly increase significantly the probability of changing livestock type/breeds, livestock diversification, livelihood diversification and mobility by 62.5, 47.6, 44.4 and 52.7 percent respectively in pastoral agro-ecosystem (Table 7). On the other hand, key informants and focus group discussion participants have argued that drought occurrence frequency affects households' vulnerability to climate change. They added, for instance, households who face drought yearly have a limited option of adaptation strategies. 
Table 7: Marginal effects of multinomial logistic regression model for determinants of adaptation options in Pastoral agro-ecosystem

\begin{tabular}{|c|c|c|c|c|c|}
\hline Explanatory variables & $\begin{array}{c}\text { Water } \\
\text { harvesting }\end{array}$ & $\begin{array}{c}\text { Changing } \\
\text { livestock } \\
\text { type/breeds }\end{array}$ & $\begin{array}{c}\text { Livestock } \\
\text { diversification }\end{array}$ & $\begin{array}{c}\text { Livelihood } \\
\text { diversification }\end{array}$ & $\begin{array}{l}\text { Migration/ } \\
\text { mobility }\end{array}$ \\
\hline Gender & $0.935 * * *$ & $0.952 * * *$ & $0.994 * * *$ & $0.992 * * *$ & $-0.951 * * *$ \\
\hline Age & 0.077 & 0.096 & $0.151 * *$ & $0.138^{*}$ & $0.129 *$ \\
\hline Marital status & -0.015 & 0.016 & 0.056 & 0.107 & -0.479 \\
\hline Family planning & $-0.648 * * *$ & $-0.730 * * *$ & $-0.796 * * *$ & $-0.791 * * *$ & $-0.617 * * *$ \\
\hline Household size & -0.722 & -0.709 & $-0.486^{*}$ & -0.326 & -0.876 \\
\hline Number of dependents & -0.346 & $-0.661 *$ & $-0.642 *$ & -0.558 & -0.354 \\
\hline Formal education & $-0.752 * * *$ & $-0.769 * * *$ & $-0.839 * * *$ & $-0.839 * * *$ & $-0.711 * * *$ \\
\hline Adult education & $-0.830 * * *$ & $-0.857 * * *$ & $-0.912 * * *$ & $-0.903 * * *$ & $-0.821 * * *$ \\
\hline Access to information & $0.690^{*}$ & $0.763 * * *$ & $0.839 * * *$ & $0.825 * * *$ & 0.480 \\
\hline Farming experience & -0.080 & -0.164 & $-0.185^{*}$ & -0.169 & -0.147 \\
\hline Health status & $0.966 * * *$ & $0.962 * * *$ & $0.996 * * *$ & $0.996 * * *$ & $0.983 * * *$ \\
\hline Social networks & $0.604 * * *$ & $0.672 * * *$ & $0.806^{* * *}$ & $0.779 * * *$ & $0.721 * * *$ \\
\hline Institutional membership & 0.061 & 0.145 & 0.283 & 0.319 & -0.096 \\
\hline \multicolumn{6}{|l|}{ Land ownership } \\
\hline Irrigation water access & $0.760 * * *$ & 0.809 & 0.879 & 0.855 & 0.825 \\
\hline Road distance & 0.973 & 0.372 & $-0.744 * *$ & $-0.563 * *$ & 0.343 \\
\hline Market distance & 0.416 & 0.442 & 0.639 & 0.585 & 0.328 \\
\hline Clean water access & $0.847 * * *$ & $0.824 * * *$ & $0.937 * * *$ & $0.941 * * *$ & $0.739 * *$ \\
\hline Mobile phone & 0.188 & 0.478 & 0.213 & 0.077 & 0.281 \\
\hline Saving & -0.168 & $-0.545^{* * *}$ & $-0.399 *$ & $-0.394 *$ & -0.194 \\
\hline \multicolumn{6}{|l|}{ Credit taking } \\
\hline Livestock ownership $* * * * *$ & 0.072 & 0.085 & $0.115^{* *}$ & $0.119 * *$ & 0.050 \\
\hline Non-agricultural income & $0.942 * * *$ & $0.961 * * *$ & $0.994 * * *$ & $0.992 * * *$ & $0.957 * * *$ \\
\hline Agricultural extension & $0.643^{*}$ & $0.804 * * *$ & $0.903 * * *$ & $0.870 * * *$ & $0.750 * * *$ \\
\hline \multicolumn{6}{|l|}{ Access to credit institution } \\
\hline Market access & 0.637 & $0.941 * * *$ & $0.979 * * *$ & $0.953 * * *$ & $0.925 * * *$ \\
\hline School distance & -0.080 & -0.163 & -0.165 & -0.182 & -0.093 \\
\hline Health post distance & $-0.651 *$ & $-0.777 *$ & $-0.096 * * *$ & $-0.101 * * *$ & $0.748 *$ \\
\hline Perception of temp. increase & $0.919 * * *$ & $0.942 * * *$ & $0.980 * * *$ & $0.973 * * *$ & $0.943 * * *$ \\
\hline Perception of Rainfall decrease & $0.987 * * *$ & $0.991 * * *$ & $0.999 * * *$ & $0.998 * * *$ & $0.990 * * *$ \\
\hline Drought occurrence frequency & -0.200 & $0.625 * * *$ & $0.476^{* *}$ & $0.444 *$ & $0.527 * *$ \\
\hline \multicolumn{6}{|l|}{ Crop failure } \\
\hline Livestock death & 0.234 & 0.487 & 0.443 & 0.346 & 0.063 \\
\hline Water scarcity & $0.557 * *$ & $0.623 * * *$ & $0.656 * * *$ & $0.723 * * *$ & $0.706^{* * *}$ \\
\hline Food shortage & -0.006 & -0.759 & -0.730 & -0.438 & -0.781 \\
\hline Conflict occurrence & 0.511 & $-0.684 * *$ & $-0.781 * * *$ & $-0.719 * * *$ & $-0.894 * * *$ \\
\hline \multicolumn{6}{|l|}{ Diagnostics } \\
\hline Base category & & $\begin{array}{c}\text { No } \\
\text { adaptation }\end{array}$ & & & \\
\hline Number of observations & & 33 & & & \\
\hline LR chi - square & 42.2 & 44.5 & 32.5 & 37.7 & 35.5 \\
\hline Log likelihood & -103.4 & -92.1 & -98.1 & -95.5 & -96.4 \\
\hline Pseudo R - square & 0.297 & 0.294 & 0.214 & 0.265 & 0.256 \\
\hline $\begin{array}{l}\text { Source: Field Survey, } 2014 \\
\text { Note: } * * * \text { significant at } 1 \%, * * \\
* * * * 4 \text { timads are equal to } 1 \text { he } \\
* * * * * \text { Tropical Livestock Unit } \\
=0.5 \text {, sheep/goat }=0.1 \text {, chicken }\end{array}$ & $\begin{array}{l}\text { nificant at } 5 \\
\text { U) convers } \\
0.01 \text { (Sourc }\end{array}$ & $\begin{array}{l}* \text { significan } \\
\text { factors: cam } \\
\text { AO, 1987). }\end{array}$ & $10 \%$ & 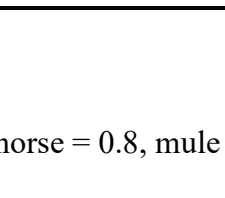 & 7 \\
\hline
\end{tabular}

\section{Crop Failure}

Crop failure increases significantly the probability of water harvesting, livestock diversification and migration by 47.4, 42.4 and 29 percent respectively in highland mixed farming agro-ecosystem (Table 4). The possible reason might be when households face crop failure usually there is drought that in turn initiates them to harvest water for the next time not to face similar problem. Similarly, as it was observed and confirmed by key informants and 
participants from the focus group discussion, households who face crop failure are more likely to practice migration. Crop failure also decreases significantly the probability of livelihood diversification by 38 percent in lowland mixed farming agro-ecosystem (Table 5). This might be as crop production is the major livelihood strategy when households face crop failure they will lose the income from farm. Crop failure increases significantly the probability of water harvesting, changing livestock type/breeds, livestock diversification and mobility by 99.5 , 99.8, 98.8 and 99.9 percent respectively in agro-pastoral agro-ecosystem (Table 6). Key informants and focus group discussion participants have confirmed by stating that crop failure increases practicing some adaptation strategies like water harvesting, changing planting date, crop diversification, and irrigation while decreasing practicing some adaptation strategies like livelihood diversification.

\section{Livestock Death}

Livestock deaths increase significantly the probability of soil and water conservation by 71.7 percent in highland mixed farming agro-ecosystem (Table 4). This might be due to the fact that most of the households do more soil and water conservation works on their farm to increase crop productivity and cover the incomes obtained from livestock when they face livestock deaths. On the other hand, livestock death decreases significantly the probability of changing crop type/variety and livestock diversification by 54 and 46.8 percent respectively in lowland mixed farming agro-ecosystem (Table 5). This is because when there are enough livestock; households most likely have enough oxen to plough their land and consequently diversify with different crops types or varieties. On the other hand, when there is livestock death due to climate change effects it may affect some species of livestock and the diversity of the livestock in which the household own might be decreased. Livestock death increases significantly the probability of changing livestock type/breeds by 59.8 percent in agro-pastoral agro-ecosystem (Table 6). Key informants and focus group discussion participants have confirmed by stating that livestock death increases practicing some adaptation strategies like changing livestock type/breeds, and livestock diversification while decreasing practicing some adaptation strategies like changing crop type and variety, crop diversification and livelihood diversification. Previous studies confirm this indicating that communities facing high temperatures leads to pasture shortages, increased pressure on available pasture, and livestock deaths which in turn decreases households income (Riche et al., 2009).

\section{Water Scarcity}

Water scarcity increases significantly the probability of water harvesting by 34.9 percent in highland mixed farming agro-ecosystem (Table 4). Similarly, water scarcity increases significantly the probability of water harvesting, crop diversification, irrigation and livelihood diversification by 56.8, 38.3, 50.7 and 38.6 percent respectively in lowland mixed farming agro-ecosystem (Table 5). This is because that when there is surface or ground water scarcity households are more likely to harvest water and prefer less water consuming crops while diversifying crops both in rain-fed and irrigation agriculture. Water scarcity increases significantly the probability of livelihood diversification by 58.6 percent in agro-pastoral agro-ecosystem (Table 6). The probable reason is that when households are suffering from water scarcity, they should diversify their livelihood strategies to minimize the risk resulted from such problem. Water scarcity increases significantly the probability of water harvesting, changing livestock type/breeds, livestock diversification, livelihood diversification, and mobility by 55.7, 62.3, 65.6, 72.3 and 70.6 percent respectively in pastoral agro-ecosystem (Table 7). Key informants and focus group discussion participants have confirmed by stating that water scarcity increase practicing some adaptation strategies like water harvesting, changing planting date and irrigation. Previous studies corroborate this indicating that success of climate change adaptation depends on availability of water in drought-prone areas (Selvaraju et al., 2006).

\section{Food Shortage}

Food shortage increases significantly the probability of changing crop type/variety, crop diversification, changing livestock type/breeds, livestock diversification and livelihood diversification by 55.7, 79.7, 53.5, 86.5 and 78.9 percent respectively in highland mixed farming agro-ecosystem (Table 4). Similarly, food shortage increases significantly the probability of irrigation and mobility by 57.1 and 50.9 percent respectively in lowland mixed farming agro-ecosystem (Table 5). The possible reason might be when households face food shortage; they would strive to change the situation through various mechanisms such as irrigation and migration. Key informants and focus group discussion participants have confirmed by stating that food shortage increase practicing some adaptation strategies like water harvesting, changing livestock type/breeds, crop diversification and irrigation to overcome such problem. However, some key informants and focus group discussion participants have argued that food shortage affects the performance of the labor force which in turn decreases the practice of different labor demanding adaptation options, as they do not get enough calories to accomplish their task efficiently and effectively. Food shortage increases significantly the probability of livelihood diversification and migration/mobility by 80.6 and 86.2 percent respectively in agro-pastoral agro-ecosystem (Table 6). The probable 
reason might be when households face food shortage they are most likely to migrate to urban areas in search of casual labor and even to engage into other income generating practices like begging. Likewise, the major food for agro-pastoralist is obtained from livestock, and when there is food shortage means there are no enough water and pasture for their livestock and this in turn makes them more likely to practice mobility.

\section{Conflict}

Conflict decreases significantly the probability of crop diversification by 21.9 percent respectively in highland mixed farming agro-ecosystem (Table 4). The possible reason might be when there is conflict, neighboring households may not cooperate each other to practice adaptation practices. Conflict decreases significantly the probability of irrigation, changing livestock type/breeds and livestock diversification by 61.2 and 19.8 and 23.6 percent respectively in lowland mixed farming agro-ecosystem (Table 5). This is because when there is conflict between households, they would not use the available limited resources like water together efficiently. Buhaug et al. (2010) confirmed that if a certain society is unable to adjust to the new challenges, it might lapse into conflict, with one group trying to secure an increasing share of the diminishing resources by force. Conflict decreases significantly the probability of changing livestock type/breeds, livestock diversification and mobility by 87.6, 59.9 and 55.3 percent respectively in agro-pastoral agro-ecosystem (Table 6). Mobility allows pastoralists to avoid overgrazing and to evade disease, conflict or drought conditions; however, conflicts may reduce social capital within a community (Hassen, 2008). Consequently, such condition may not allow the pastoralists to move freely in search of water and pasture. This in turn protects the pastoralists not to practice other adaptation strategies like livestock diversification because of lack of pasture. On the contrary, conflict decreases significantly the probability of mobility by percent (Table 6). Similarly, conflict decreases significantly the probability of changing livestock type/breeds, livestock diversification, livelihood diversification, and mobility by 68.4, 78.1, 71.9 and 89.4 percent respectively in pastoral agro-ecosystem (Table 7). Similarly, as it was observed and asserted by key informants the occurrence of conflict has hindered the mobility of agro-pastoralists in search of water and pasture especially during drought.

\section{CONCLUSIONS AND POLICY IMPLICATIONS \\ Conclusions}

Agro-ecosystem difference created a difference in employing adaptation strategies to climate change. As a result, while the majority of households in highland and lowland mixed farming agro-ecosystems have employed most of the adaptation strategies identified in this study, households in agro-pastoral and pastoral agro-ecosystems employ some of them. Moreover, the percentage of households who practice those few adaptation strategies is lower in pastoral and agro-pastoral agro-ecosystems except mobility. This might be one possible reason why the agro-pastoralists and pastoralists are more vulnerable than the highland and lowland mixed farming agroecosystems. Previous studies Atinkut and Mebrat (2016) and Hadgu et al. (2015) have supported this finding stating that farmers living in different agro-ecological setting use different adaptation options in response to climate variability and change.

The practices of different adaptation strategies are determined by demographic characteristics, access to or ownership of livelihood capitals, use or adoption of technologies, institutional setups and access to such institutions, and exposure of households to environmental factors. For instance, environmental and other related factors such as perceiving temperature increase, perceiving rainfall decrease, frequent occurrence of drought, crop failure, livestock death, water scarcity, food shortage, and conflict occurrence have influenced households in practicing different adaptation strategies. For instance, a study conducted by Atinkut and Mebrat (2016), has supported this finding by stating that farmers' perception to climate variability affects the choice of farmers' adaptation measures; and perception of households' to the increasing temperature was found to be positively and significantly correlated with the choice of crop-diversification and soil and water conservation.

\section{Policy Implications}

Different agro-ecosystems use different adaptation strategies to climate change. As a result, it is recommended that concerned stakeholders should work jointly to maximize the potential adaptation strategies of each agroecosystem. More specifically, mixed farming agro-ecosystems stakeholders should work jointly to tap irrigation potential and agro-pastoral and pastoral agro-ecosystems stakeholders should work to tap the potential in livestock diversification and mobility.

The analyses of the determinants to adaptation options suggest a number of different policy options. As to demographic variables: female-headed households are more vulnerable. On the other hand, divorced/widowed women are increasing in the study locality. Hence, the concerned organs should work jointly to empower femaleheaded households in the study area.

Different livelihood capitals play a crucial role in determining the adoption of various adaptation options in the study areas. For instance, educational status is very low in the study area while access to information is 
important to adapt to climate change impacts. However, it is when households are educated or literate they can easily access information. Hence, the concerned organs should work jointly to educate households in the area especially through adult education. Similarly, access to irrigation water is found to be important to adapt to climate change impacts. However, there are several problems such as lack of irrigation scheme and lack of power for some of those who had irrigation scheme. Hence, it is recommended to develop irrigation scheme for those who do not have and avail power supply who have the irrigation scheme but not functional.

Technology adoption is found very important to adapt to climate change impacts. For example, technologies like water harvesting, and availability of irrigation scheme found to be very important in responding to climate change impacts. Hence, it is recommended to expand these technologies in the study areas.

Institutional factors influence the adoption of various adaptation strategies in the study areas. For example, access to credit and agricultural extension services found to be vital for responding to climate change impacts. Thus, government policies should ensure to have access to affordable credit and appropriate extension services.

Finally, environmental factors are found significant in influencing the adoption of many adaptation options in different agro-ecosystems. For instance, perception of temperature increase and rainfall decrease found to be important in responding to climate change impacts. Consequently, crop failure, livestock death, water scarcity, food shortage and conflict occurrence were making the study households more sensitive to climate extremes. Hence, the concerned organs in each agro-ecosystem should work jointly to minimize the sensitivity of households to the above mentioned factors.

Conflict of Interest: There is no conflict of interest

\section{REFERENCES}

Acquah, H. D. (2011). Farmers Perception and Adaptation to Climate Change: A Willingness to Pay Analysis. University of Cape Coast, Cape Coast, Ghana.

Addis, E., and Assefa, S. (2013). Social Protection Systems in Pastoral Areas of Ethiopia: The Case of Fentale District, Oromia Region. In Devereux and Melese (ed.), Informal and Formal Social Protection Systems in Sub-Saharan Africa. OSSREA, Addis Ababa, Ethiopia.

Anderson, S., Morton, J., and Toulmin, C. (2010). Climate Change for Agrarian Societies in Drylands: Implications and Future Pathways In Mearns and Norton (ed.). 2010: Social Dimensions of Climate Change. Equity and Vulnerability in a Warming World. NewYork.

Assefa, K. (2009). Overview of Climate Change in Ethiopia. National Meteorological Agency. Addis Ababa, Ethiopia.

Atinkut, B., and Mebrat, A. (2016). Determinants of farmers choice of adaptation to climate variability in Dera woreda, south Gondar zone, Ethiopia. Environmental Systems Research, 5, 6.

Balew, S., Agwata, J., and Anyango, S. (2014). Determinants of Adoption Choices of Climate Change Adaptation Strategies in Crop Production by Small Scale Farmers in Some Regions of Central Ethiopia. Journal of Natural Sciences Research, 4(4), 2014.

Bazezew, A., Bewket, W., and Nicolau, M. (2013). Rural households' livelihood assets, strategies and outcomes in drought-prone areas of the Amhara Region, Ethiopia: Case Study in Lay Gaint District. African Journal of Agricultural Research, 8 (46), 5716-5727.

Berg, L. (2009). Qualitative Research Methods for the Social Sciences. A Pearson Education Company. USA.

Bewket, W. (2009). Rainwater Harvesting as a Livelihood Strategy in the Drought-Prone Areas of the Amhara Region of Ethiopia.

Bewket, W. (2012). Climate change perceptions and adaptive responses by smallholder farmers in central highlands of Ethiopia, International Journal of Environmental Studies, 69(3), 507-523.

Boko, M., Niang, I., Nyong, A., Vogel, C., Githeko, A., Medany, M., Osman-Elasha, B., Tabo, R., and Yanda, P. (2007). Africa. Climate Change 2007: Impacts, Adaptation and Vulnerability. Contribution of Working Group II to the Fourth Assessment Report of the Intergovernmental Panel on Climate Change, M.L. Parry, O.F. Canziani, J.P. Palutikof, P.J. van der Linden and C.E. Hanson, Eds., Cambridge University Press, Cambridge UK, 433-467.

Brooks, N. (2003). Vulnerability, risk and adaptation: A conceptual framework. Tyndall Centre for Climate Change Research and Centre for Social and Economic Research on the Global Environment (CSERGE) School of Environmental Sciences, University of East Anglia.

Buhaug, H., Gleditsch, N. P., and Theisen, O. M. (2010). Implications of Climate Change for Armed Conflict In Mearns and Norton (ed.). 2010: Social Dimensions of Climate Change. Equity and Vulnerability in a Warming World. NewYork.

Dawson, C. (2009). Practical Research Methods: A user-friendly guide to mastering research techniques and projects. How to Books. UK.

De Vaus, D. (2001). Research Design in Social Research. Sage Publications, London. 
Deressa, T.T. (2010). Assessment of the vulnerability of Ethiopian agriculture to climate change and farmers adaptation strategies. PhD Thesis. Faculty of Natural and Agricultural Sciences, University of Pretoria; Pretoria, South Africa.

Deressa, T.T., Hassan, R.M., Ringler, C., Alemu, T., and Yesuf, M. (2009). Determinants of Farmers' choice of adaptation methods to Climate change in the Nile Basin of Ethiopia. Global Environmental Change, 19, 248255.

Dessler, A. E., and Parson, E. A. (2006). The Science and Politics of Global Climate Change: A Guide to the Debate. Cambridge University Press, Cambridge, New York, Melbourne, Madrid, Cape Town, Singapore, São Paulo.

Devereux, S. (2000). Food Insecurity in Ethiopia: A Discussion Paper for Department for International Development. Sussex: Institute of Development.

Di Falco, S., and Veronesi, M. (2012). How African Agriculture Can Adapt to Climate Change? A Counterfactual Analysis from Ethiopia: London School of Economics.

Di Falco, S., Veronesi, M., and Yesuf, M. (2011). Does Adaptation to Climate Change Provide Food security? A Micro-perspective from Ethiopia. American Journal of Agricultural Economics. Oxford University Press.

FAO. (2010). Strengthening Capacity for Climate Change Adaptation in the Agriculture Sector in Ethiopia: Proceedings of the National Workshop, Nazreth, Ethiopia.

Federal Democratic Republic of Ethiopia (FDRE). (2014). Ethiopia's Climate Resilient Green Economy: Climate Resilience Strategy for Agriculture and Forestry. Addis Ababa, Ethiopia.

Gbetibouo, G. A. (2009). Understanding Farmers' Perceptions and Adaptations to Climate Change and Variability. The Case of the Limpopo Basin, South Africa.

Gebremichael, Y., and Kifle, M. (2009). Local innovation in climate-change adaptation by Ethiopian pastoralists. PROLINNOVA-Ethiopia and Pastoralist Forum Ethiopia (PFE).

Gebru, G. W., and Beyene, F. (2012). Rural household livelihood strategies in drought-prone areas: The case of Gulomekeda District, Eastern Zone of Tigray National Regional State, Ethiopia.

Gecho, Y., Ayele, G., Lemma, T., and Alemu, D. (2014). Rural household livelihood strategies: Options and determinants in the case of Wolaita Zone, Southern Ethiopia. Social Sciences, 3(3), 92-104.

Getachew, S., Tilahun, T., and Teshager, M. (2014). Determinants of Agro-pastoralists Climate change Adaptation Strategies: Case of Rayitu Woreda, Oromia Region, Ethiopia. Research Journal of Environmental Sciences, $8(6), 300-317$.

Greene, W. H. (2003). Econometric analysis, 5th ed. Prentice Hall, Upper Saddle River, New Jersey: PrenticeHall.

Gregory, P. J., Ingram, J. S. I., and Brklacich, M. (2005). Climate change and food security. Philosophical Transactions: Biological Sciences, 360 (1463), 2139-2148.

Guzmán, J. M., Martine, G., McGranahan, G., Schensul, D., and Tacoli, C. (2009). Population Dynamics and Climate Change. UNFPA (United Nations Population Fund) and IIED (International Institute of Environment and Development). New York and London.

Hadgu. G., Tafesse, K., Mamo, G., and Belay, K. (2015). Farmers' climate change adaption options and their determinants in Tigray Region, Northern Ethiopia. African Journal of Agricultural Research.

Hassan, R., and Nhemachena, C. (2008). Determinants of African Farmers Strategies for adapting to climate Change: multinomial choice analysis. African Journal of Agriculture and Resource Economics, 2(1).

Hisali, E., Birungi, P., and Buyinza, F. (2011). Adaptation to climate change in Uganda: Evidence from micro level data. Global Environmental Change, (21), 1245-1261.

Intergovernmental Panel on Climate Change (IPCC). (2001). Climate change: impacts, adaptation and vulnerability. IPCC Working Group II Report. Cambridge, UK: Cambridge University Press.

Intergovernmental Panel on Climate Change (IPCC). (2014). Climate change: impacts, adaptation and vulnerability. IPCC Working Group II Report. Cambridge, UK: Cambridge University Press.

Kansiime. M.K., S. K. Wambugu, and C. A. Shisanya. 2014. Determinants of Farmers' Decisions to Adopt Adaptation Technologies in Eastern Uganda. Journal of Economics and Sustainable Development, 5 (3), 2222-2855.

Kassa, B., Beyene, F., and Winfried, M. (2005). Coping with drought among pastoral and agro-pastoral communities in Ethiopia. Journal of Rural Development, 28, 185-210.

Kelly. P. M., and Adger, W. N. (2000). Theory and Practice in Assessing Vulnerability to Climate Change and Facilitating Adaptation. Climatic Change, 47(4), 925-1352.

Kuriakose, A. T., Bizikova, L., and Bachofen, C.A. (2009). Assessing Vulnerability and Adaptive Capacity to Climate Risks: Methods for Investigation at Local and National Level. World Bank, Washington DC.

Land Management Component. (2006). Agro-ecosystems analysis and agro-ecological zoning, a handbook. LaoSwedish Upland Agriculture and Forestry Research Program. National Agriculture and Forestry Research Institute. Vientiane, Lao PDR. 
Lautze, S., Kidanu, Y., Raven-Roberts, A., Young, H., Kebede, G., and Learning, J. (2003). Risk and vulnerability in Ethiopia: Learning from the past, responding to the present, preparing for the future. Report for the U.S. Agency for International Development. Addis Ababa, Ethiopia.

Legesse, B., Yared, A., and Bewket, W. (2013). Smallholder Farmers Perceptions and adaptation to Climate Variability and Climate Change in Doba District, West Hararghe, Ethiopia. Asian Journal of Empirical Research, 3(3), 251-265.

Lohr, S.L. (2010). Sampling: Design and Analysis. Brooks/Cole, Cengage Learning, USA.

Maddison, D. (2006). The perception to and adaptation to climate change in Africa. CEEPA. Discussion Paper No. 10. Center for Environmental Economics and Policy in Africa. Pretoria: University of Pretoria.

Mearns, R., and Norton, A. (2010). Social Dimensions of Climate Change. Equity and Vulnerability in a Warming World. NewYork.

Mengistu. D. K. (2011). Farmers Perceptions and Knowledge of Climate Change and their coping strategies to the related hazards: Case study from Adiha, Central Tigray Ethiopia. Agricultural sciences, 2 (2), 138-145.

Ministry of Agriculture (MoA). (2000). Agro-ecological zonations of Ethiopia. Addis Ababa, Ethiopia.

Mulatu, N. (2013). Determinants of Farmers' Preference for Adaptation Strategies to Climate Change: Evidence from North Shoa Zone of Amhara Region. Munich Personal RePEc Archive.

National Meteorological Services Agency (NMA). (2007). National Adaptation Program of Action for Ethiopia. National Meteorological Agency, Addis Ababa, Ethiopia.

Ndambiri, H. K., Ritho, C. N., and Mbogoh, S. G. (na). An evaluation of farmers' perceptions of and adaptation to the effects of climate change in Kenya. International Journal of Food and Agricultural Economics, 1(1), 75-96.

Negatu, W., Hassen, A., and Kebede, A. (2011). A comparative Analysis of Vulnerability of Pastoralists and Agropastoralists to Climate Change: A Case study in Yabello Woreda of Oromia Region, Ethiopia. Ethiopian Journal of Development Research, 33 (1), 61-95.

Opiyo, F.O., Wasonga, O. V., and Nyangito, M. M. (2014). Measuring household vulnerability to climate-induced stresses in pastoral rangelands of Kenya: Implications for resilience programming. Pastoralism: Research, Policy and Practice, 4,10.

Orindi, V., Ochieng, A., Otiende, B., Bhadwal, S., Anantram, K., Nair, S., Kumar, V., and Kelkar, U. (2006). Mapping climate vulnerability and poverty in Africa: Report to the Department for International Development, ILRI, Nairobi, Kenya.

Pastoralist Community Development Project (PCDP). (2005). Social Analysis and Indigenous Livelihood Strategies in Afar Pastoral Communities. Addis Ababa: Federal Project Coordination Unit.

Piya. L., Maharjan, K. L., and Joshi, N. P. (2012). Vulnerability of rural households to climate change and extremes: Analysis of Chepang households in the Mid-Hills of Nepal. Selected Paper prepared for presentation at the International Association of Agricultural Economists (IAAE) Triennial Conference, Foz do Iguaçu, Brazil, 18-24 August, 2012.

Regassa, S., Givey, R. C., and Castillo, E. (2010). The Rain Doesn't Come on Time Anymore: Poverty, Vulnerability and Climate Variability in Ethiopia. Oxfam International.

Riché, B., Hachileka, E., Awuor, C. B., and Hammill, A. (2009). Climate - related vulnerability and adaptive capacity in Ethiopia's Borana and Somali communities. Final assessment report. Save the Children UK and CARE International.

Roncoli, C., Okoba, B., Gathaara, V., Ngugi, J., and Nganga. T. (2010). Adaptation to Climate Change for Smallholder Agriculture in Kenya: Community-Based Perspectives from Five Districts.

Selvaraju. R., Subbiah, A.R., Baas, S., and Juergens, I. (2006). Livelihood adaptation to climate variability and change in drought-prone areas of Bangladesh. FAO, Italy.

Shiferaw, A. (2014). Smallholder Farmers Adaptation Strategies to Climate Change in Ethiopia: Evidence from Adola Rede Woreda, Oromia Region. Journal of Economics and Sustainable Development, 5(7), 2222-2855.

Simane, B., Zaitchik, B. F., and Ozdogan, M. (2013). Agro-ecosystem Analysis of the Choke Mountain Watersheds, Ethiopia. Sustainability, 5, 592-616.

Stern, N. (2007). The Economics of Climate Change: The Stern Review. Cambridge University Press, Cambridge, UK, pp. 712.

Stige, L.C., Stave, J., Chan, K., Ciannelli, L., Pattorelli, N., Glantz, M., Herren, H., Stenseth, N. (2006). The effect of climate variation on agro-pastoral production in Africa. PNAS, 103, 3049-3053.

Tadesse, T., Hassan, R.M., and Ringler, C. (2008). Measuring Ethiopian Farmers' Vulnerability to Climate Change Across Regional States. International Food Policy Research Institute (IFPRI).

Tazeze. A., Haji, J., and Ketema, M. (2012). Climate Change Adaptation Strategies of Smallholder Farmers: The Case of Babilie District, East Harerghe Zone of Oromia Regional State of Ethiopia. Journal of Economics and Sustainable Development, 3(14).

Teklewold, H., Dadi, L., Yami, A., and Dana, N. (2006). Determinants of adoption of poultry technology: A double 
hurdle approach. Livestock Research for Rural Development, 18 (3).

Tesfay, G. K. (2014). Smallholder Farmers' Adaptation Strategies to Climate Change in Ethiopia: Evidence from Adwa Woreda of Tigray Region. An MSc Thesis, Mekelle University, Mekelle, Ethiopia.

Teshome, M. (2014). A Comparative Study of Farmers Vulnerability and Adaptation to Climate Change in Three Agro-ecologies of Northwest Ethiopia. PhD thesis, Addis Ababa University, Addis Ababa, Ethiopia.

Tessema, Y.A., Aweke, C. S., and Endris, G. S. (2013).Understanding the process of adaptation to climate change by small-holder farmers: the case of east Hararghe Zone, Ethiopia. Agricultural and Food Economics, 1, 13.

Tesso, G., Emana, B., and Ketema, M. (2012). Analysis of vulnerability and resilience to climate change induced shocks in North Shewa, Ethiopia. Agricultural Sciences, 3(6), 871-888.

Tizale, C.Y. (2007). The dynamics of soil degradation and incentives for optimal management in the Central Highlands of Ethiopia. PhD thesis. Faculty of Natural and Agricultural Sciences, University of Pretoria; Pretoria, South Africa.

UN OCHA Pastoralist Communication Initiative. (2007). The Future of Pastoralism in Ethiopia.

UNDP. (2006). Human Development Report: Beyond scarcity: Power, poverty and the global water crisis. Palgrave Macmillan, New York, USA.

Van Ginkel, M., Sayer, J., Sinclair, F., Aw-Hassan, A., Bossio, D., Craufurd , P., El Mourid, M., Haddad, N., Hoisington, D., Johnson, N., Velarde, C. L., Mares, V., Mude, A., Nefzaoui, A., Noble, A., Rao, K. P. C., Serraj, R., Tarawali, S., Vodouhe, R., and Ortiz, R. (2013). An integrated agro-ecosystem and livelihood systems approach for the poor and vulnerable in dry areas.

Vincent K., Cull, T., Chanika, D., Hamazakaza, P., Joubert, A., Macome, E., Mutinhodza-Davies, C. (2013). Farmers response to climate variability and Change in Southern Africa-is it coping or adaptation? Climate Development, 5(3), 194-205.

Vincent, K. (2004). Creating an index of social vulnerability to climate change for Africa. Working Paper 56. Norwich: Tyndall Center for Climate Change Research.

Vincent, K. (2007). Uncertainty in adaptive capacity and the importance of scale. Global Environmental Change, $17(1), 12-24$.

WHO. (2003). The World Health Report: Shaping the Future. Geneva, Switzerland.

Worku, I. (2011). Road Sector Development and Economic Growth in Ethiopia. EDRI Working Paper 4. Addis Ababa, Ethiopia: Ethiopian Development Research Institute.

World Bank. (2003). Ethiopia: Risk and Vulnerability Assessment. Draft Report. Washington DC.

World Bank. (2006). Reengaging in Agricultural Water Management: Challenges and options. The World Bank, Washington DC.

World Bank. (2010). Development and Climate Change. The Social Dimensions of Climate Change Adaptation in Ethiopia. Washington DC.

World Development Report (WDR). (2010). Development and Climate Change. World Bank. NewYork. 